\title{
Activation of Pro-survival CaMK4 $\beta /$ CREB and Pro-death MST1 signaling at early and late times during a mouse model of prion disease
}

\author{
Rory H Shott ${ }^{1}$, Anna Majer ${ }^{3,4}$, Kathy L Frost ${ }^{3}$, Stephanie A Booth ${ }^{3,4}$ and Luis M Schang ${ }^{1,2^{*}}$
}

\begin{abstract}
Background: The signaling pathways most critical to prion disease pathogenesis are as yet incompletely characterized. We have developed a kinomics approach to identify signaling pathways that are dysregulated during prion pathogenesis. The approach is sensitive and specific enough to detect signaling pathways dysregulated in a simple in vitro model of prion pathogenesis. Here, we used this approach to identify signaling pathways dysregulated during prion pathogenesis in vivo.

Methods: Mice intraperitoneally infected with scrapie (strain RML) were euthanized at 70, 90, 110, 130 days post-infection (dpi) or at terminal stages of disease (155-190 dpi). The levels of 139 protein kinases in brainstem-cerebellum homogenates were analyzed by multiplex Western blots, followed by hierarchical clustering and analyses of activation states.

Results: Hierarchical and functional clustering identified CaMK4 $\beta$ and MST1 signaling pathways as potentially dysregulated. Targeted analyses revealed that CaMK4 $\beta$ and its downstream substrate CREB, which promotes neuronal survival, were activated at 70 and $90 \mathrm{dpi}$ in cortical, subcortical and brainstem-cerebellum homogenates from scrapie-infected mice. The activation levels of CaMK4ß/CREB signaling returned to those in mock-infected mice at $110 \mathrm{dpi}$, whereas MST1, which promotes neuronal death, became activated at $130 \mathrm{dpi}$.
\end{abstract}

Conclusion: Pro-survival CaMK4//CREB signaling is activated in mouse scrapie at earlier times and later inhibited, whereas pro-death MST1 signaling is activated at these later times.

Keywords: Prion disease, Kinomics, Protein kinase, Multiplex Western blots, CaMK4ß, CREB, MST1

\section{Background}

Prion diseases are a family of invariably lethal chronic neurodegenerative diseases that affect humans (kuru; Creutzfeldt-Jakob disease, CJD; Gerstmann-SträusslerScheinker disease, GSS; fatal familial insomnia, FFI), and other species such as cattle (bovine spongiform encephalopathy, BSE), goat, sheep (scrapie), deer, elk and moose (chronic wasting disease, CWD) [1,2]. Human prion diseases can be infectious (acquired), inherited (genetic), or sporadic. The latter are the most common, accounting for approximately $85 \%$ of cases [3]. Whereas

\footnotetext{
* Correspondence: luis.schang@ualberta.ca

'Department of Biochemistry and Centre for Prions and Protein Folding

Diseases (CPPFD), University of Alberta, Edmonton, AB, Canada

${ }^{2}$ Li Ka Shing Institute of Virology, University of Alberta, Edmonton, AB,

Canada

Full list of author information is available at the end of the article
}

the inherited and acquired cases may be suspected, from the risk facts, before the onset of clinical symptom, the sporadic cases can only be diagnosed after the onset of clinical symptoms [4].

The neuropathology of prion diseases is characterized by gliosis, spongiform degeneration, and neuronal death. The conversion of the cellular prion protein $\left(\operatorname{Pr} \mathrm{P}^{\mathrm{C}}\right)$ into its pathological conformation $\left(\mathrm{PrP}^{\mathrm{Sc}}\right)$ is essential for pathogenesis. Neuronal death and disease progression were prevented in scrapie-infected mice by conditional ablation of $\operatorname{PrP}^{\mathrm{C}}$ at the time when $\operatorname{PrP}^{\mathrm{Sc}}$ was first detected [5]. Inhibition of $\mathrm{PrP}^{\mathrm{C}}$ conversion to $\mathrm{PrP}^{\mathrm{Sc}}$ is thus a validated target for therapeutic intervention. Many compounds have been identified to inhibit $\operatorname{PrP}$ conversion or the accumulation of $\operatorname{PrP}^{\mathrm{Sc}}$ in vitro [6,7]. Only one, however, the diphenyl pyrazole 
derivative anle138b [3-(1,3-benzodioxol-5-yl)-5-(3-bromophenyl)-1H-pyrazole], prolonged survival of scrapieinfected mice when treatment was started after the onset of clinical signs of disease [8]. Unfortunately, none affected survival of patients with CJD, GSS, or FFI [9-18]. Another compound that prolonged survival of scrapie-infected mice after the onset of clinical disease is the calcineurin/ protein phosphatase 3 inhibitor FK506. FK506, however, did not affect the levels of $\operatorname{PrP}^{\mathrm{C}}$ or the accumulation of $\operatorname{PrP}^{\mathrm{Sc}}$ [19], indicating that FK506 acts downstream from the accumulation of $\mathrm{PrP}^{\mathrm{Sc}}$. As FK506 is a known (calcineurin) signaling inhibitor, these results suggest that dysregulated signaling downstream of PrP conversion is an alternative therapeutic target against prion diseases.

Protein kinases (and phosphatases) modulate by reversible phosphorylation the function, localization, or activities of approximately one-third of cellular proteins [20]. Protein kinases are therefore critical regulators of signal transduction. Their dysregulation is implicated in the pathogenesis of many chronic diseases, including neurodegenerative diseases such as Alzheimer's and Parkinson's [21-23]. Consequently, protein kinases are major therapeutic targets. It is estimated that up to $30 \%$ of the research and development budget of the pharmaceutical industry is invested in protein kinase inhibitors [24,25]. For example, protein kinase inhibitors are the largest group of new cancer therapeutics [26]. Thirty-one protein kinase inhibitors are in clinical use, over 500 are involved in approximately 2,700 clinical trials, and thousands more are in various stages of preclinical development ([26-28] and summary of [29]). Protein kinase inhibitors therefore constitute a rapidly growing group of clinical drugs that have the potential to considerably impact treatment of chronic diseases.

Considering the critical roles that protein kinases play in the pathogenesis of other chronic neurodegenerative diseases, it is not surprising that they also participate in the pathogenesis of prion diseases. For example, the activation of vascular endothelial growth factor receptor (VEGFR) inhibited death of cultured neurons treated with the neurotoxic prion peptide PrP106-126 [30]. Death of PrP106-126treated cultured neurons was also inhibited by Abelson leukemia oncogene cellular homolog (c-Abl) knockdown [31] and treatment with the glycogen synthase kinase 3 (GSK3) inhibitor lithium [32]. Scrapie-infected mice treated with the protein kinase R-like endoplasmic reticulum kinase (PERK) inhibitor GSK2606414 survived longer than vehicle-treated mice [33]. The phosphoinositide-dependent kinase 1 (PDK1) inhibitor BX912 also prolonged survival of scrapie-infected mice [34]. Protein kinase inhibitors may have good potential in prion disease therapeutics. Unfortunately, the signaling pathways most critical to prion disease pathogenesis have yet to be fully identified.

We have developed a kinomics approach to identify signaling pathways dysregulated during prion disease pathogenesis (Shott et al., companion paper). We initially tested the approach in a simplified in vitro model of prion disease pathogenesis (Shott et al., companion paper). Here, we applied the approach to mice infected with mouse-adapted scrapie. We identified two signaling pathways dysregulated during scrapie pathogenesis. The calcium/calmodulin-dependent protein kinase, beta isoform (CaMK4 3 )/cAMP response element-binding protein (CREB) signaling pathway, which promotes neuronal survival, was activated at earlier times but its activation state returned to that in mock-infected mice later on. Mammalian STE20-like protein kinase 1 (MST1) signaling, which promotes neuronal death, was, in contrast, activated at these later times. The dysregulation of CaMK4 $\beta$ / CREB and MST1 signaling pathways may therefore be critical to the neurodegeneration in scrapie infected mice.

\section{Results}

PrP ${ }^{\text {res }}$ is first detected in scrapie-infected mice at $130 \mathrm{dpi}$ Mock-infected mice or mice infected intraperitoneally with scrapie (mouse-adapted strain RML) were euthanized at 70, 90, 110, 130 days post-infection (dpi), or at terminal stages of disease (155-190 dpi). Brains were dissected into (i) cortical (cerebrum), (ii) subcortical (including thalamus, hypothalamus and hippocampus) and (iii) brainstem-cerebellum as described [35].

We first analyzed the levels of protease-resistant $\operatorname{PrP}^{\mathrm{Sc}}$ $\left(\mathrm{PrP}^{\mathrm{res}}\right)$ and total glial fibrillary acidic protein (GFAP) by Western blot. PrP ${ }^{\text {res }}$ was enriched by sodium phosphotungstic acid (NaPTA) precipitation prior to proteinase $\mathrm{K}$ (PK) treatment. As expected, $\operatorname{PrP}^{\text {res }}$ was only detected in scrapie-infected mice, and its levels increased with time of infection (Figure 1A). $\operatorname{PrP}^{\text {res }}$ was first detected in all regions at $130 \mathrm{dpi}$, and increased coordinately with the levels of GFAP from 130 dpi to terminal stages of disease (unpaired two-tail $t$-test; GFAP brainstem-cerebellum, $P=0.0388$; subcortical region, $P=0.0008$; cortical region, $P=0.0414$ ) (Figure 1B), as expected [36,37]. The levels of GFAP were also higher in the brainstem-cerebellum of scrapie-infected mice prior to $\operatorname{PrP}^{\text {res }}$ accumulation at $70 \mathrm{dpi}(P=0.0041)$ and showed a tendency to higher levels in the cortical region at $90 \mathrm{dpi}$, as observed previously [38]. The lower molecular weight form of GFAP has also been observed previously [39] and is likely the result of degradation.

\section{Primary kinomic screens identified two signaling pathways of potential interest, which are involved in neuronal death and survival}

After intraperitoneal infection, prion disease spreads in the brain caudal to rostral [40-42]. We therefore selected the brainstem-cerebellum for the primary screens, for the greatest window of opportunity to identify signaling pathways dysregulated during pathogenesis. Primary multiplex Western blots analyzed the expression levels 


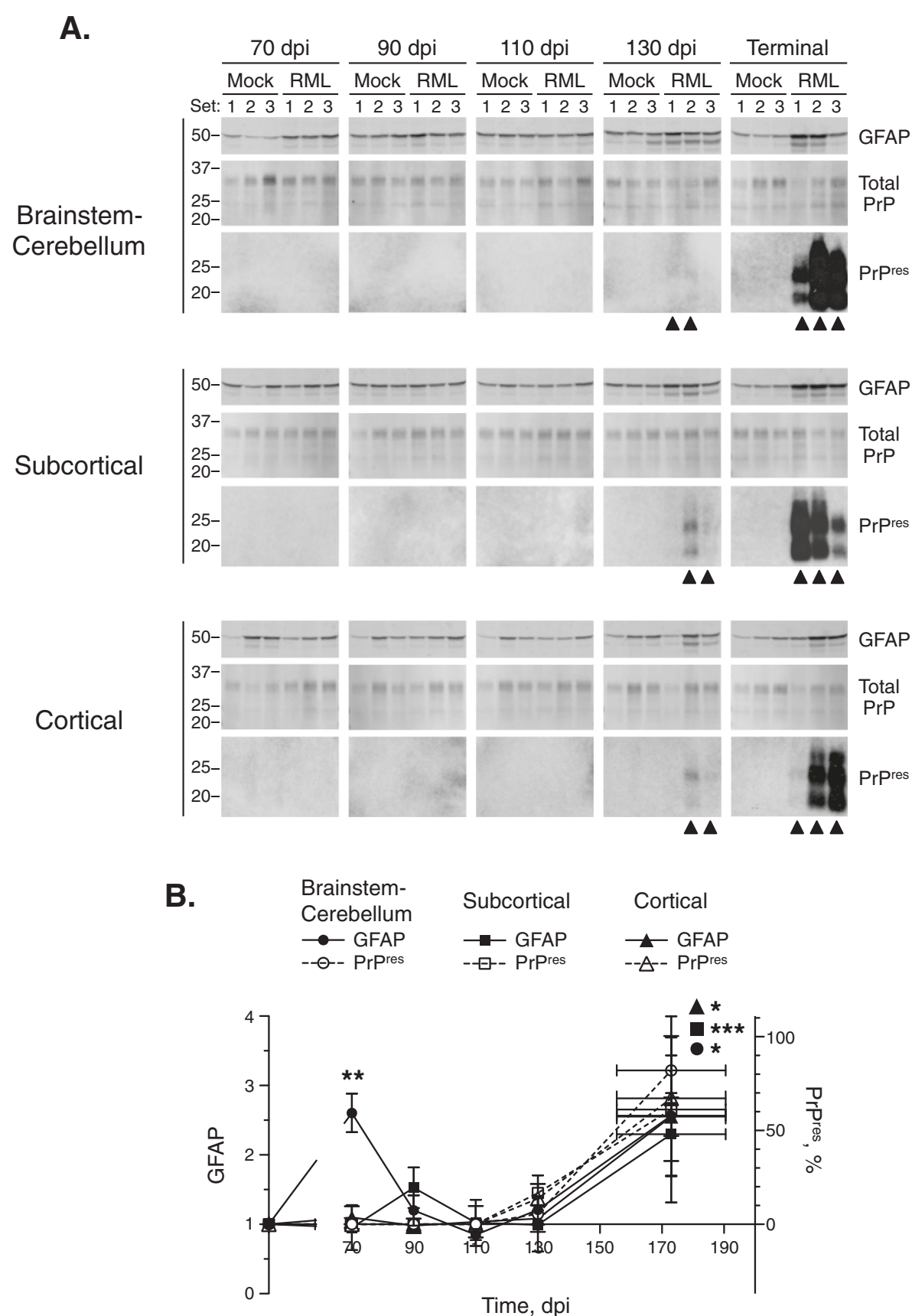

Figure 1 Levels of GFAP and PrPres during scrapie progression. (A) Western blots of GFAP, total PrP, and Prpres in homogenates of brainstem-cerebellum, subcortical region, and cortical region of three mock (Mock)- or scrapie (RML)-infected mice at 70, 90, 110, 130 dpi or at terminal stage of disease (155-190 dpi). Molecular weights in kDa are indicated on the left. Black triangles, samples in which PrPres was quantitated. (B) Time-course changes in the levels of GFAP and PrPres. Line graphs show the levels of GFAP in scrapie-infected mice normalized to the average levels in mock-infected mice at each time point. The levels of PrPres are expressed as a percentage relative to the highest level detected in each region. Mean \pm SD; $n=3$ (Mean \pm range for Prpres at $130 \mathrm{dpi}$ where $n=2$ ). Error bars on the $x$-axis, range in time of onset of terminal disease. The differences in GFAP levels in scrapie- versus mock-infected mice were analyzed by unpaired two-tail $t$-test. ${ }^{*} P<0.05 ;{ }^{* *} P<0.01$; ${ }^{* * *} P<0.001$.

of 139 protein kinases (Additional file 1: Table S1) in brainstem-cerebellum homogenates of three mock-infected and three scrapie-infected mice euthanized at 70, 90, 110, 130 dpi or at terminal stages (155-190 dpi). The antibodies included in our analyses were optimized and validated as described (Shott et al., companion paper). We detected 109 protein kinases (78\% of the 139 tested), most of which were differentially expressed in scrapie- as compared to mock-infected mice. For example, CaMK4 $\beta$ was expressed to higher levels in scrapie- than in mock-infected mice at 
70 dpi (Figure 2A), and dual leucine zipper kinase (DLK) to lower levels at $130 \mathrm{dpi}$ (Figure 2B). Ten protein kinases were not detected in one set of mock- and scrapie-infected mice at one time point (tropomyosin-related kinase B [TrkB], Set 1 at $70 \mathrm{dpi}$; membrane-associated tyrosine/ threonine-specific cdc2-inhibitory kinase [Myt1], Set 2 at $110 \mathrm{dpi}$; v-Raf murine sarcoma viral oncogene homolog B1 [B-Raf], ribosomal protein S6 kinase, 70 kilodalton, polypeptide 1 [p70S6K], serine/threonine-protein kinase D3 [PKD3], protein kinase R [PKR], serine/threonine-protein kinase N2 [PRK2], STE20-like serine/threonine-protein kinase [SLK], TRAF2 and NCK-interacting protein kinase [TNIK], and tropomyosin-related kinase C [TrkC], Set 3 at $130 \mathrm{dpi}$ ). Five other proteins (calcium/calmodulindependent protein kinase 1 alpha [CaMK1 $\alpha$ ], cyclin D1, cyclin G1, p25 and p35) were not resolved in one set at 70, 90, 110, and 130 dpi. Mitogen-activated protein kinase kinase kinase 5 (ASK1) and mitogen-activated protein kinase kinase kinase 1 (MEKK1) were not quantitated in one set at $90 \mathrm{dpi}$, or two at terminal stages, due to transfer or blotting artifacts, respectively. The raw densitometric data obtained from all other protein kinases was normalized to data from the mock-infected mice, $\log _{2}$ transformed and analyzed by unsupervised hierarchical clustering.

We first blindly clustered the scrapie-infected mice to evaluate the changes in protein kinase expression during disease progression (Figure 3). The most distantly related cluster consisted of the two mice euthanized at $130 \mathrm{dpi}$ with the highest levels of $\mathrm{PrP}^{\mathrm{res}}$, and one mouse euthanized at terminal stages of disease (130-1, 130-2, TER-1). The second most distantly related cluster consisted of two mice euthanized at $70 \mathrm{dpi}(70-2,70-3)$. All other mice clustered in two subclusters. One of them consisted of the third mouse euthanized at $70 \mathrm{dpi}(70-1)$, two mice euthanized at $90 \mathrm{dpi}$, and all three mice euthanized at $110 \mathrm{dpi}$. The other consisted of mice euthanized at $90 \mathrm{dpi}, 130$ $\mathrm{dpi}$, and terminals stages of disease (90-1, 130-3, TER2 , TER-3). The mice therefore clustered largely based on time after infection, suggesting that levels of protein kinase expression in mice changed in response to scrapie pathogenesis.

The data was next clustered to identify the expression levels of protein kinases which changed similarly in scrapieinfected mice during disease progression (Figure 4A). Protein kinases with similar changes in expression may, or may not, also be involved in the same signaling pathway. To identify those that were, we performed literature and signal transduction database searches. Mitogen-activated protein kinase 12 (p38y), ribosomal S6 kinase 1 (RSK1), v-yes-1 Yamaguchi sarcoma viral related oncogene homolog (Lyn), and CaMK4 $\beta$, which clustered together because they were expressed to similarly higher levels in scrapie- than in mock-infected mice at $70 \mathrm{dpi}$, are all involved in an $\mathrm{N}$ methyl-D-aspartate receptor (NMDAR)-regulated CaMK4 $\beta$ signaling pathway that promotes neuronal survival (Figure 4B, $i$ ). MST1, DLK and mitogen-activated protein kinase 9 (JNK2) (p54; $\alpha 2 / \beta 2$ isoforms), which clustered together because they were expressed to similarly lower levels in scrapie- than in mock-infected mice at $130 \mathrm{dpi}$, are all involved in an MST1 signaling pathway that promotes neuronal death (Figure 4B, ii). Although dual specificity mitogen-activated protein kinase kinase 7 (MKK7), which is also involved in this pathway, clustered distantly, its expression levels were also somewhat lower in scrapiethan in mock-infected mice at $130 \mathrm{dpi}$.

Primary screens of brainstem-cerebellum homogenates from scrapie-infected mice therefore identified two signaling pathways which may be dysregulated during pathogenesis. The NMDAR-regulated CaMK $4 \beta$ signaling pathway promotes neuronal survival and the expression levels of the protein kinases involved changed (increased) the most at earlier times. Conversely, the MST1 signaling pathway promotes neuronal death, and the expression levels of involved protein kinases were most affected (decreased) at later times.

\section{CaMK4 $\beta /$ CREB signaling is activated at early stages of scrapie in mice}

The NMDAR-regulated CaMK4 $\beta$ signaling pathway promotes neuronal survival though the activation of CREB [43]. We therefore analyzed the expression levels of CREB. We also analyzed the expression levels of neuronal nitric oxide synthase (nNOS) and the scaffold protein postsynaptic density protein 95 (PSD-95), which associate with, or are regulated by, RSK1, Lyn and p38y at NMDARs [44-46]. CaMK4ß, CREB, p38y, RSK1, and PSD-95 levels in the brainstem-cerebellum of scrapie-infected mice were different from those in mock-infected mice (nonlinear regression analysis; CaMK4 $\beta, P=0.0404$; $C R E B, P=0.0372 ; \mathrm{p} 38 \gamma$, $P=0.0369 ;$ RSK1, $P=0.0471$; PSD-95, $P=0.0147$ ) (Figure 5). Consistent with the higher levels of RSK1, Lyn, p38y, and CaMK $4 \beta$ in the brainstem-cerebellum of scrapie-infected mice at $70 \mathrm{dpi}$, the levels of nNOS and CREB were also higher at this time (two-tail paired ratio $t$-test; $\mathrm{nNOS}, P=$ 0.0434; CREB, $P=0.0341$ ) (Figure 5). We expanded our analyses to the subcortical and cortical regions. CREB levels were also significantly higher in the subcortical and cortical regions of scrapie-infected mice, but at $90 \mathrm{dpi}$ (subcortical region, $P=0.0196$; cortical region, $P=0.0481$ ) (Figure 5). CaMK $4 \beta$ and CREB levels changed coordinately in both the brainstem-cerebellum and subcortical regions (Figure 5).

We next performed targeted tertiary (phosphorylation state-specific) analyses to characterize the activation state of (NMDAR-regulated) CaMK4 $\beta / C R E B$ signaling in scrapieinfected mice. The activation of Lyn and RSK1 involves autophosphorylation on Y396 or S380, respectively [47-50]. Activated RSK1 (P-S380) inhibits nNOS by phosphorylation 


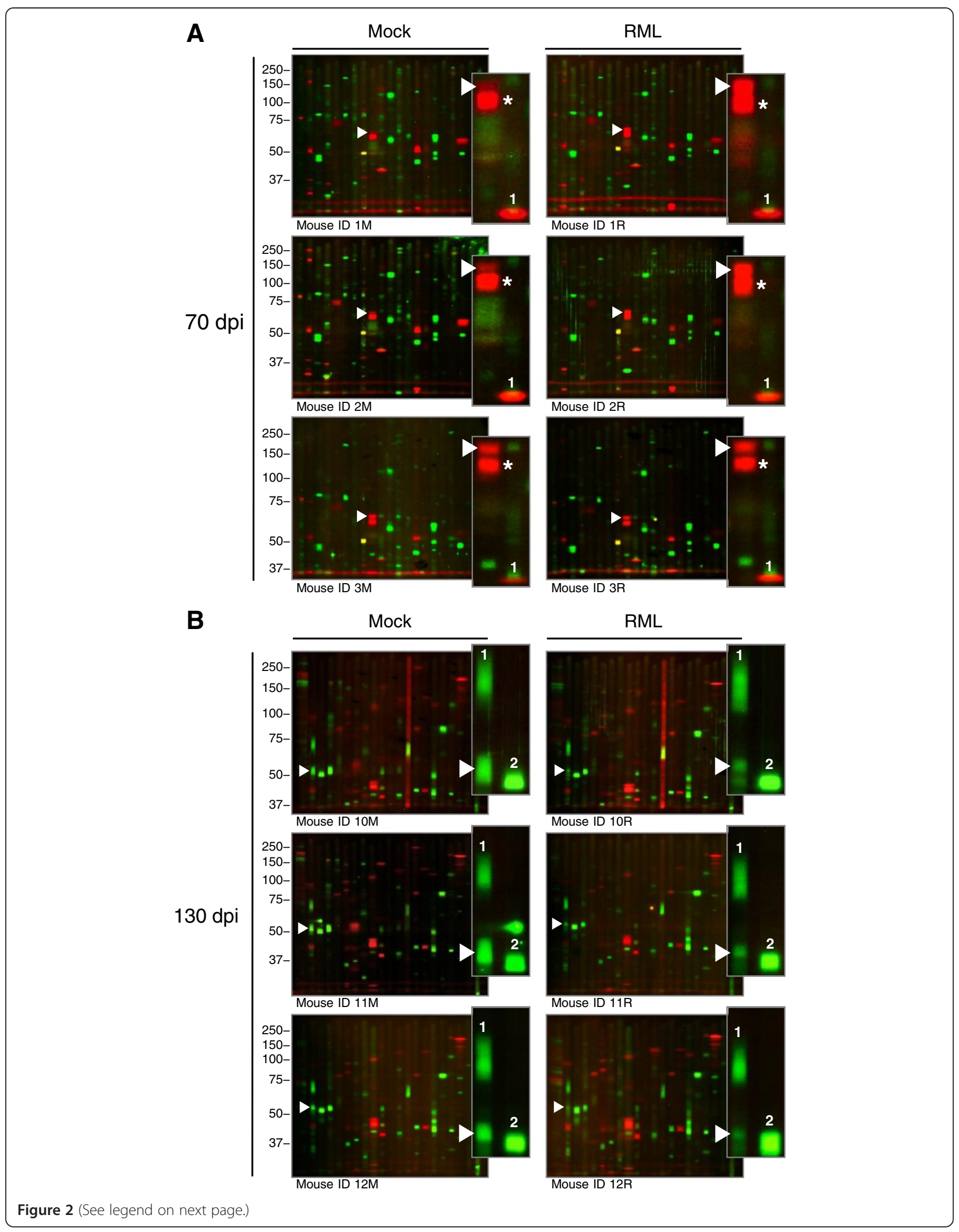


(See figure on previous page.)

Figure 2 Differential expression of protein kinases in scrapie- versus mock-infected mice at $\mathbf{7 0}$ and $\mathbf{1 3 0}$ dpi. Primary multiplex Western blots analyzing the expression levels of 139 protein kinases in three mock- or scrapie-infected mice at 70 (A) or 130 (B) dpi. Mice identified by ID numbers; M, mock-infected; RML, RML-infected. Molecular weights in kDa are indicated on the left. The protein kinases CaMK4 $\beta$ ( $\mathbf{A}$; probed with antibody set 1) and DLK (B; probed with antibody set 2) are indicated by white arrowheads and enlarged to illustrate their differential expression in scrapie- versus mock-infected mice. The antibody used to detect CaMK4 $\beta$ also detects CaMK4 (red band, indicated by the asterisks), the levels of which remain constant. The expression levels of the other protein kinases tested in the same or adjacent lanes also remained constant or were expressed differently than CaMK4 $\beta$ and DLK (A, CK1 $\varepsilon$ [red band] indicated by $1 ;$ B, LIMK1 indicated by 1 and GSK3a indicated by 2). Apparent signal above GSK3a in mouse ID $11 \mathrm{M}$ is an artifact.

on S847 [45]. Activated p38 (P-T180/Y182) phosphorylates PSD-95 on S290 [46]. Activated CaMK4ß (P-T196; corresponding to human T200) phosphorylates CREB on S133 $[51,52]$. Phosphorylated CREB promotes transcription of genes that encode proteins involved in neuronal survival [53,54]. There is no antibody specific for T180/Y182 phosphorylation on only p38 $\gamma$. We therefore used an antibody that detects T180/Y182 phosphorylation on all p38 isoforms (p38 $\alpha, \mathrm{p} 38 \beta, \mathrm{p} 38 \gamma, \mathrm{p} 38 \delta$ ). In summary, we analyzed the levels of activating phosphorylation of p38 (P-T180/ Y182), Lyn (P-Y396), RSK1 (P-S380), CaMK4ß (P-T196), and CREB (P-S133), and the levels of inhibitory phosphorylation of nNOS (P-S847). No antibody specific for $\mathrm{p} 38$ phosphorylated PSD-95 (P-S290) was available.

As their total levels, the levels of activated CaMK4 $\beta$ (PT196) and CREB (P-S133) changed coordinately. Their levels were significantly higher in the brainstem-cerebellum of scrapie-infected than of mock-infected mice at 70 and $90 \mathrm{dpi}$ (two-tail paired ratio $t$-test; CaMK4 $\beta P=0.0256[70$ dpi], 0.0248 [90 dpi]; CREB $P=0.0197$ [70 dpi], 0.0086 [90 dpi]) (Figure 6). The levels of phosphorylated CREB in the subcortical and cortical regions were also significantly higher (subcortical region $P=0.0412$ [90 dpi]; cortical region $P=0.0093$ [70 dpi], 0.0376 [90 dpi]), or at least there was a trend to higher levels in scrapie-infected than in mock-infected mice (subcortical region $P=0.0936$ [70 dpi]) (Figure 6). The levels of activated CaMK4 $\beta$ in the subcortical and cortical regions at 70 and 90 dpi were similar in scrapie- and mock-infected mice. The levels of activated p38 (P-T180/T182) were significantly higher in scrapie-infected than in mock-infected mice at 70 and 90 dpi (brainstem-cerebellum $P=0.0225$ [90 dpi]; subcortical region $P=0.0106$ [70 dpi]; cortical region $P=0.0014$ [70 dpi]) but also at 110 and $130 \mathrm{dpi}$ (brainstem-cerebellum $P=0.0465$ [110 dpi]; cortical region $P=0.0116$ [130 dpi]) (Figure 6). There was no correlation between the levels of activated RSK1 (P-S380) and nNOS (P-S847) in the different brain regions (Additional file 2: Figure S1). The levels activated Lyn (P-Y396) were mostly unchanged in scrapieinfected mice relative to mock-infected mice.

In summary, CaMK $4 \beta / C R E B$ signaling was activated in scrapie-infected mice at early times. The expression levels and the levels of phosphorylated CREB (P-S133) and activated CaMK4 $\beta$ (P-T196) were higher in scrapiethan in mock-infected mice at 70 and $90 \mathrm{dpi}$.

\section{MST1 is activated at late stages of mouse scrapie}

The MST1 signaling pathway mediates neuronal death by activating forkhead box protein O3 (FOXO3) [55]. We therefore analyzed the expression levels of FOXO3 in targeted secondary Western blots of brainstem-cerebellum homogenates from scrapie-infected mice at 70, 90, 110, $130 \mathrm{dpi}$ or at terminal stages of disease. Consistent with the lower expression levels of DLK (two-tailed paired ratio

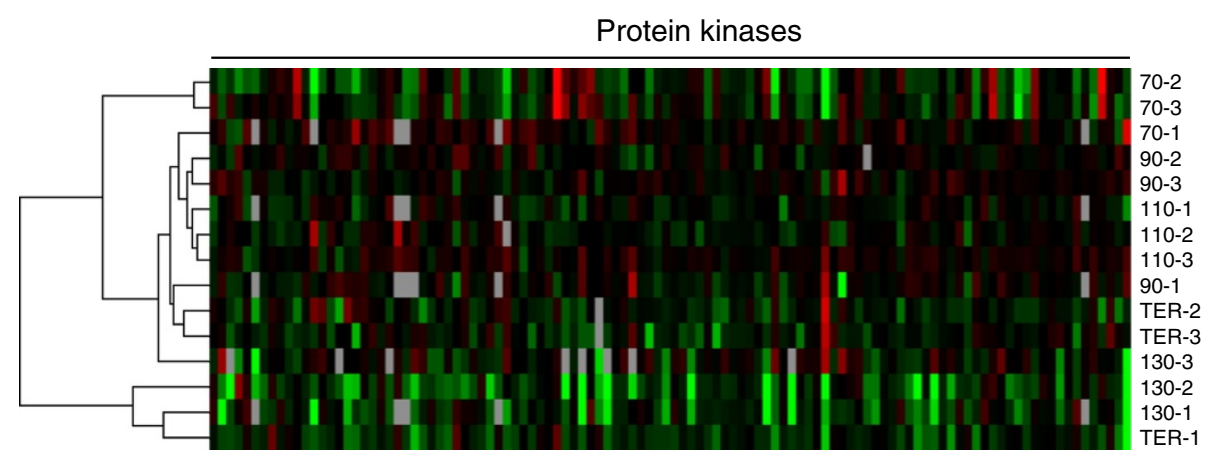

Figure 3 Blind clustering of scrapie-infected mice results in their grouping largely by time after infection. Hierarchical clustering of the scrapie-infected mice euthanized at 70,90, 110, 130 dpi or at terminal stage of disease (TER) using the densitometric data of the 109 protein kinases detected in primary multiplex Western blots. The normalized and $\log _{2}$ transformed levels of protein kinase expression for each set $(1,2,3$ - consisting of one scrapie-and one mock-infected mouse euthanized at each time point) were clustered using Gene Cluster 3.0 software (Euclidean distance; complete linkage) and presented using Java Treeview. 


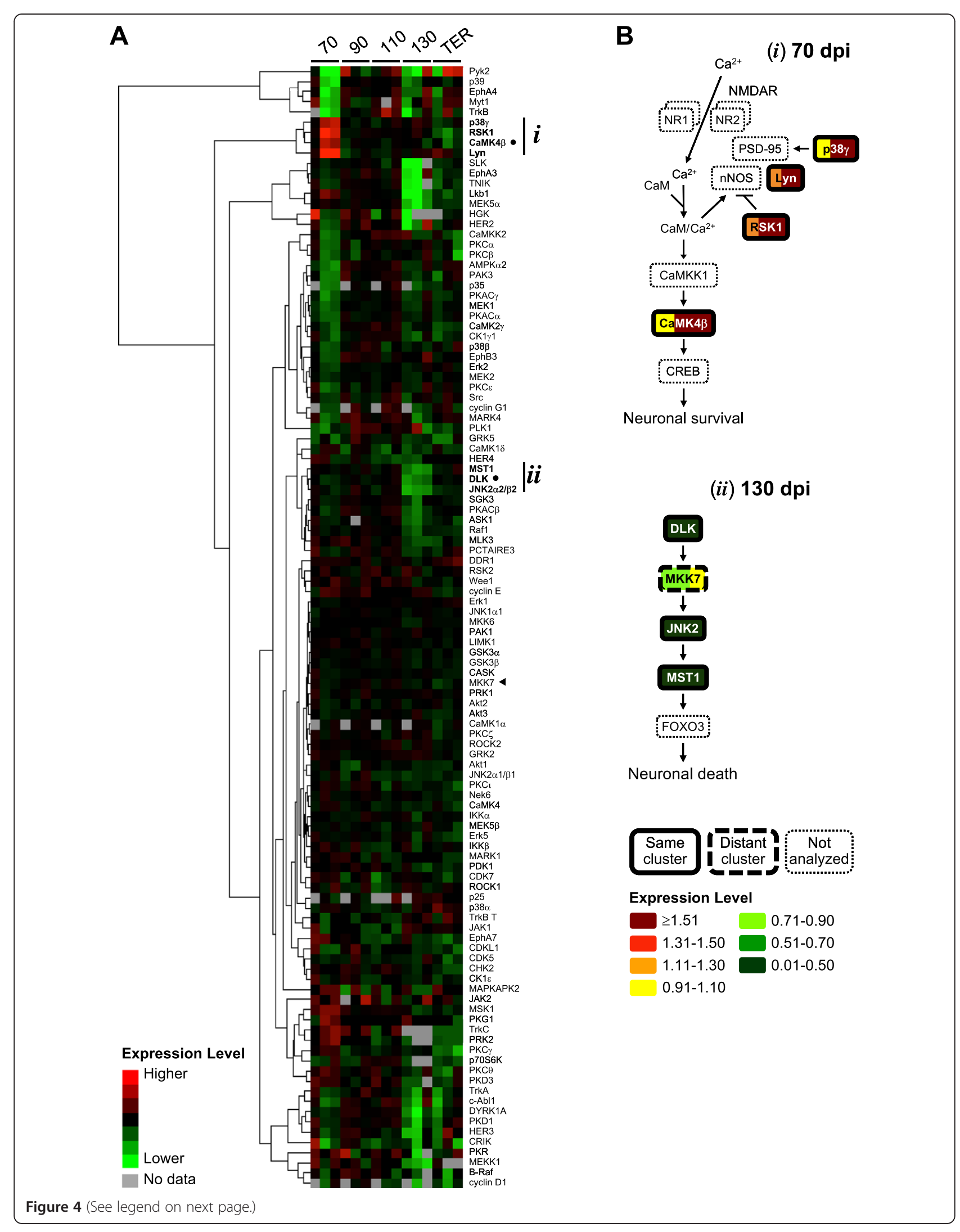


(See figure on previous page.)

Figure 4 Identification of two signaling pathways of potential interest involved in neuronal survival and death. (A) Hierarchical clustering the normalized and $\log _{2}$ transformed densitometric data of the expression levels of 109 protein kinases detected in primary multiplex Western blots of brainstem-cerebellums of scrapie-infected mice at 70, 90, 110, $130 \mathrm{dpi}$ or at terminal stage of disease (TER). Red, higher expression level; green, lower expression level; grey, no data (protein kinases that were not resolved, not detected, or not quantitated due to transfer or blotting artifacts). Cluster (i) consists of protein kinases involved in the NMDAR-regulated CaMK4 $\beta$ signaling pathway. Cluster (ii) consists of protein kinases involved in the MST1 signaling pathway. The protein kinases highlighted in Figure 2, CaMK4 $\beta$ and DLK, are indicated by $(\bullet)$, and MKK7 is indicated by (4). (B) Expression levels of protein kinases involved in the CaMK4 $\beta$ and MST1 signaling pathways, and included in the primary multiplex Western blots, at $70 \mathrm{dpi}$ (top panel) and $130 \mathrm{dpi}$ (bottom panel), respectively. Color bars indicate the levels in each of the three scrapie-infected mice normalized to those in mock-infected mice.

$t$-test; $P=0.0182)$, JNK2 $(P=0.0063)$, and MST1 $(P=$ $0.0095)$, FOXO3 levels were also significantly lower $(P<$ $0.0001)$ in the brainstem-cerebellum of scrapie- than of mock-infected mice at $130 \mathrm{dpi}$ (Figure 7). The levels of DLK, MKK7, and JNK2 were more similar in the subcortical and cortical regions of mock- and scrapieinfected mice than in their brainstem-cerebellum (Figure 7) (Additional file 3: Figure S2). However, MST1 and FOXO3 were still expressed to significantly lower levels in the cortical region of scrapie- than of mockinfected mice at $130 \mathrm{dpi}$ (MST1, $P=0.0384$; FOXO3, $P=$ 0.0090) (Figure 7). MST1 levels also appeared to be different in the subcortical region of scrapie- or mock-infected mice (nonlinear regression analysis; MST1, $P=0.0513$ ), but did not reach statistical significance at any single time point. The differential expression of MST1 and FOXO3 in the brainstem-cerebellum and cortical region, albeit to differing degrees, supports a model in which MST1/FOXO3 signaling is dysregulated during progression of scrapie.

To test this model, we performed targeted (phosphorylation state-specific) tertiary Western blots to characterize the activation state of MST1/FOXO3 signaling. MST1 is activated by autophosphorylation on T183 (P-T183) [56]. Activated MST1 phosphorylates FOXO3 in the cytosol on S208 (corresponding to S207 in human) [55]. Phosphorylated FOXO3 (P-S208) then translocates to the nucleus where it activates transcription of genes that encode proteins involved in neuronal death. Activated MST1 is further activated by caspase- 3 cleavage. Cleaved MST1 further promotes cell death [57-60]. We analyzed the levels of activating phosphorylation of MST1 (P-T183) and FOXO3 (P-S207) and activating cleavage of MST1. MST1 activation is promoted by JNK-mediated phosphorylation on S82 [61] and active JNK2 is phosphorylated on T183/Y185. As no antibody available was specific for P-T183/Y185 of only JNK2 or P-S82 of MST1, we used antibodies that detect T183/Y185 phosphorylation on all JNK isoforms (JNK1, JNK2, JNK3; p46 [JNK1 $\alpha 1$, JNK1 $\beta 1$, JNK2 $\alpha 1$, JNK2 $\beta 1$, JNK3 $\alpha 1$ ] and p54. [JNK1 $\alpha 2$, JNK1 $\beta 2$, JNK2 $\alpha 2$, JNK2 $\beta 2$, JNK3 32$]$ ) or autophosphorylated MST1 (P-T183).

There was a trend to higher levels of activated JNK (p54; P-T183/Y185) and MST1 (P-T183) in the cortical region of scrapie-infected mice at $70 \mathrm{dpi}$ (two-tail paired ratio $t$-test; JNK [p54], $P=0.0851$; MST1, $P=0.0880$ ) (Figure 8). The levels of activated JNK were significantly higher in the subcortical region at $70 \mathrm{dpi}(P=0.0332)$, whereas those of MST1 were not $(P=0.2222)$. Cleaved MST1 and phosphorylated FOXO3 (P-S208) levels were similar in scrapie- and mock-infected mice at this time (Additional file 3: Figure S2). Levels of cleaved MST1 were significantly higher at 130 dpi in all brain regions (brainstem-cerebellum, $P=0.0452$; subcortical region, $P=0.0237$; cortical region, $P=0.0243$ ), whereas activated JNK levels were similar in scrapie- and mock-infected mice at this time (Figure 8). Levels of activated MST1 (P-T183) were significantly higher $(P=0.0215)$ in the cortical region of scrapie-infected mice at terminal stages, when the levels of cleaved MST1 had returned to levels similar to those in mock-infected mice.

In summary, MST1 signaling was activated in scrapieinfected mice at late times. Levels of cleaved MST1 were higher at $130 \mathrm{dpi}$, when total levels of MST1 and FOXO3 were lower. At terminal stages of disease, levels of activated MST1 (P-T183) were higher in scrapie- than in mock-infected mice.

\section{Discussion}

We describe the application of a new kinomics approach to an in vivo model of prion disease pathogenesis, mice intraperitoneally infected with scrapie strain RML. The primary screens identified CaMK4 $\beta$ and MST1 signaling pathways as of potential interest. Targeted analyses then tested the activation state of these pathways. CaMK4 $\beta /$ CREB signaling, which promotes neuronal survival, was activated at earlier times in scrapie-infected mice, but returned to the levels of mock-infected mice at later times. At these later times, MST1 signaling, which promote neuronal death, was activated (Figure 9).

The activation of CaMK4 $\beta / C R E B$ signaling at preclinical stages of prion disease had not been described. CREB is critical to neuronal survival. CREB/cAMP response element modulator (CREM) double knockout mice, or mice in which CREB is inhibited by overexpression of a dominant negative mutant or inhibitory peptides, suffer extensive neuronal loss [62-64]. Active CREB promotes neuronal survival by regulating transcription of "activity-regulated inhibitor of death" (AID) genes, including gadd45 $\beta$, gadd $45 \gamma$, btg2, npas4, nr4a1, inhba, atf3, ifi202b, serpinb2 $[53,54]$. CREB also regulates the transcription of 


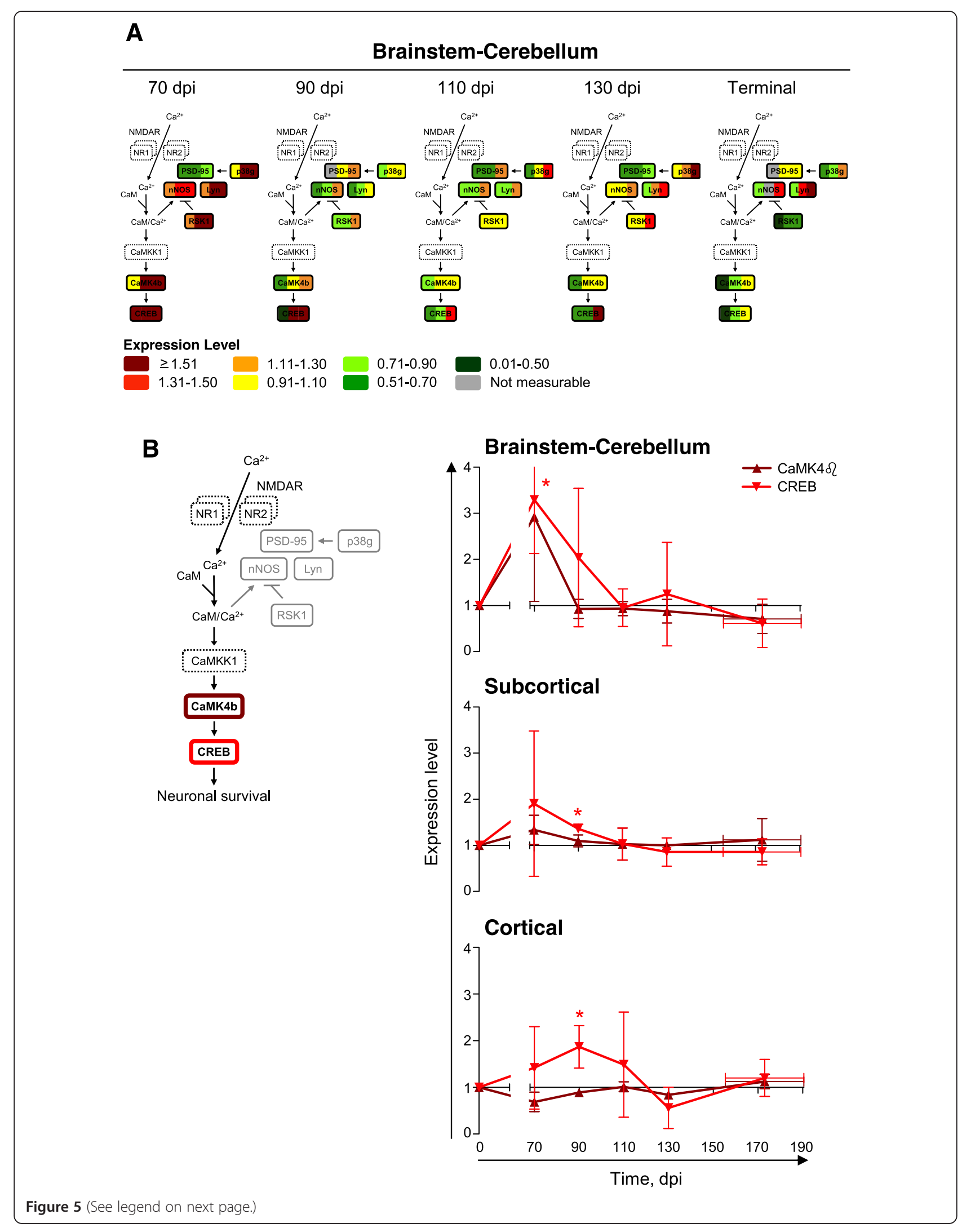


(See figure on previous page.)

Figure $\mathbf{5}$ CREB is expressed to higher levels in scrapie- than in mock-infected mice at $\mathbf{7 0}$ and $\mathbf{9 0}$ dpi. Targeted secondary analyses of the NMDAR-regulated CaMK4 $\beta$ signaling pathway in brainstem-cerebellum, subcortical and cortical regions of scrapie-infected mice at 70, 90, 110, $130 \mathrm{dpi}$ or at terminal stage of disease (TER; 155-190 dpi). (A) Expression levels of p38y, Lyn, RSK1, CaMK4 $\beta$, nNOS, CREB, and PSD-95 in the brainstem-cerebellums of each of the three scrapie-infected mice at each time point, normalized to those in the mock-infected mice, shown by color bars. The proteins in dashed lines were not analyzed. (B) Levels of CaMK4 $\beta$ and CREB in all macrodissected regions, normalized to those in the mock-infected mice, shown as time series. Mean $\pm S D ; n=3$. Error bars on the $x$-axes, range in time of onset of terminal disease. The differences in the expression levels in scrapie- versus mock-infected mice were analyzed by two-tailed paired ratio t-test. ${ }^{*} P<0.05$.

miR132-3p [65,66], which modulates synapse morphology [67]. High-throughput analyses have identified changes in many mRNAs and miRNAs, including miR132-3p, in scrapie-infected mice prior to the accumulation of $\operatorname{PrP}^{\text {res }}$ or the onset of clinical disease [68-73]. Elevated levels of miR132-3p and AID genes (gadd45 $\beta$, gadd45y, btg2, npas4, nr4a1) were observed at 70-110 dpi after infection with the same scrapie strain and by the same route of inoculation as in the current experiments [72]. Activated CaMK4 $\beta / C R E B$ signaling may well promote neuronal survival early in prion infection by upregulating the expression of miR132-3p and AID genes.

CaMK4 $/$ /CREB signaling returned to the activation levels of mock-infected mice at $110 \mathrm{dpi}$. Calcineurin regulates the activity of CaMK4 [74] and CREB [75], and elevated calcineurin activity was observed in scrapieinfected mice at clinical stages of disease [19]. Moreover, the calcineurin inhibitor FK506 prolonged survival of scrapie-infected mice and inhibited neuronal death in cultured neurons treated with PrP106-126 [19,76,77]. CaMK4/CREB signaling is therefore most likely neuroprotective in scrapie-infected mice. Decreased levels of activated CaMK4 $\beta$ (P-T196) and phosphorylated CREB (P-S133) were associated with decreased expression levels, suggesting that degradation may be involved in downregulation of this pathway. CaMK4 and CREB are degraded by calpain, a calcium-dependent protease [78,79]. Active calpain degraded CaMK4 and CREB in cultured neurons treated with hydrogen peroxide after CREB (P-S133) dephosphorylation [80]. Increased levels of calpain have been observed in in vitro and in vivo models of prion disease [81,82], and calpain inhibition limited neuronal death in prion-infected cultured organotypic cerebellar slices or cultured neurons treated with PrP106-126 [81,83,84]. CaMK4/CREB signaling activation may be inhibited in scrapie-infected mice after 90 days by dephosphorylation and degradation mediated by calpain. CaMK4 and CREB are also dephosphorylated by protein phosphatase $2 \mathrm{~A}$ (PP2A) [85-87], the activity of which has yet to be evaluated during scrapie infection.

MST1 signaling was activated at $130 \mathrm{dpi}$, which had not been described in prion disease. MST1 has been shown to be involved in other neurodegenerative diseases. Genetically modified mice that model amyotrophic lateral sclerosis (ALS) lose fewer neurons and survive longer if they are knocked out of MST1 [88]. Active MST1 (PT183) is cleaved by active (cleaved) caspase-3 [57-60], the levels of which are elevated in scrapie-infected mice (before the accumulation of $\operatorname{PrP}^{\text {res }}$ ) and in cultured neurons or neuroblastoma cells exposed to PrP106-126 or $\operatorname{PrP}^{\mathrm{Sc}}$ [89-92]. We observed elevated levels of cleaved MST1 at $130 \mathrm{dpi}$, suggesting that it is also cleaved by caspase-3 in vivo. Although cleaved MST1 retains the T183 phosphorylation site, T183 phosphorylation is not required for cleavage [56,93], and we did not detect cleaved MST1 with the phosphorylation-specific antibody. Caspase-cleaved MST1 translocates to the nucleus and induces chromatin condensation by inducing phosphorylation of histone $\mathrm{H} 2 \mathrm{~B}$ on S14 [94]. Chromatin condensation has been observed previously in scrapie-infected GT1 cells and mice [95-98]. However, caspase- 3 activation is not required for MST1 activation [56] or neuronal death in prion disease $[92,99,100]$.

MST1 activates FOXO3, which is otherwise maintained in the cytosol in an inactive state by interaction with 14-33 proteins [101]. Cleaved MST1 predominately localizes to the nucleus and is therefore unable to phosphorylate FOXO3 [102,103]. The levels of phosphorylated FOXO3 (P-S208) might have been higher (but were not statistically different) after the levels of cleaved MST1 had returned to those in mock-infected mice. Active FOXO3 upregulates transcription of genes encoding pro-apoptotic proteins including Bim (bcl-2 interacting mediator of cell death; bcl2l11), Puma (Bcl-2-binding component 3; bbc3) and Noxa (phorbol-12-myristate-13-acetate-induced protein 1; pmaip1) [104-106]. The levels of Bim, Puma, bcl2l11, bbc3 and pmaip1 are elevated in scrapie-infected mice at late stages of disease progression $[72,107,108]$, suggesting that neuronal death mediated by MST1 signaling could involve FOXO3.

The CaMK4 $\beta / C R E B$ and MST1 signaling pathways were identified in our screens because the expression levels of the involved protein kinases changed coordinately during prion disease progression (Figures 5 and 7). The CaMK4 $\beta /$ CREB signaling pathway promotes neuronal survival. CaMK4 $\beta$ and CREB were expressed to higher levels and activated at earlier stages of disease. Neurons may activate this pathway to protect themselves from prion-mediated 


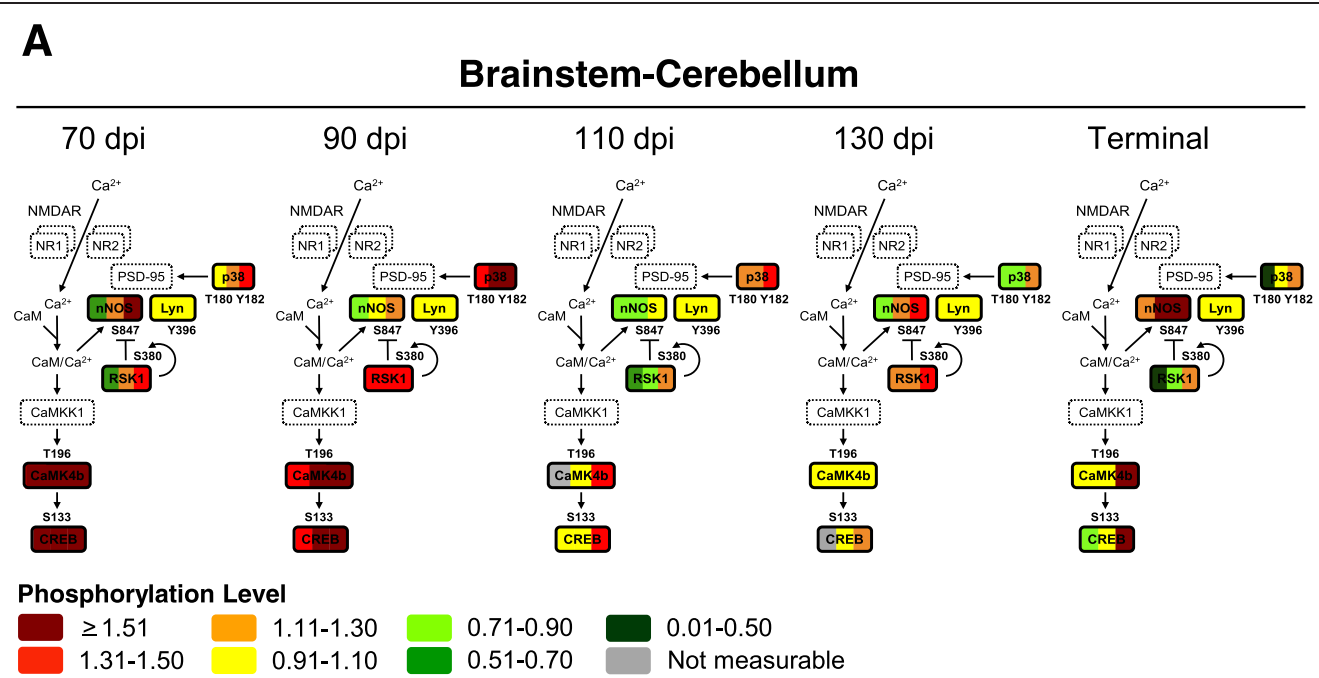

B
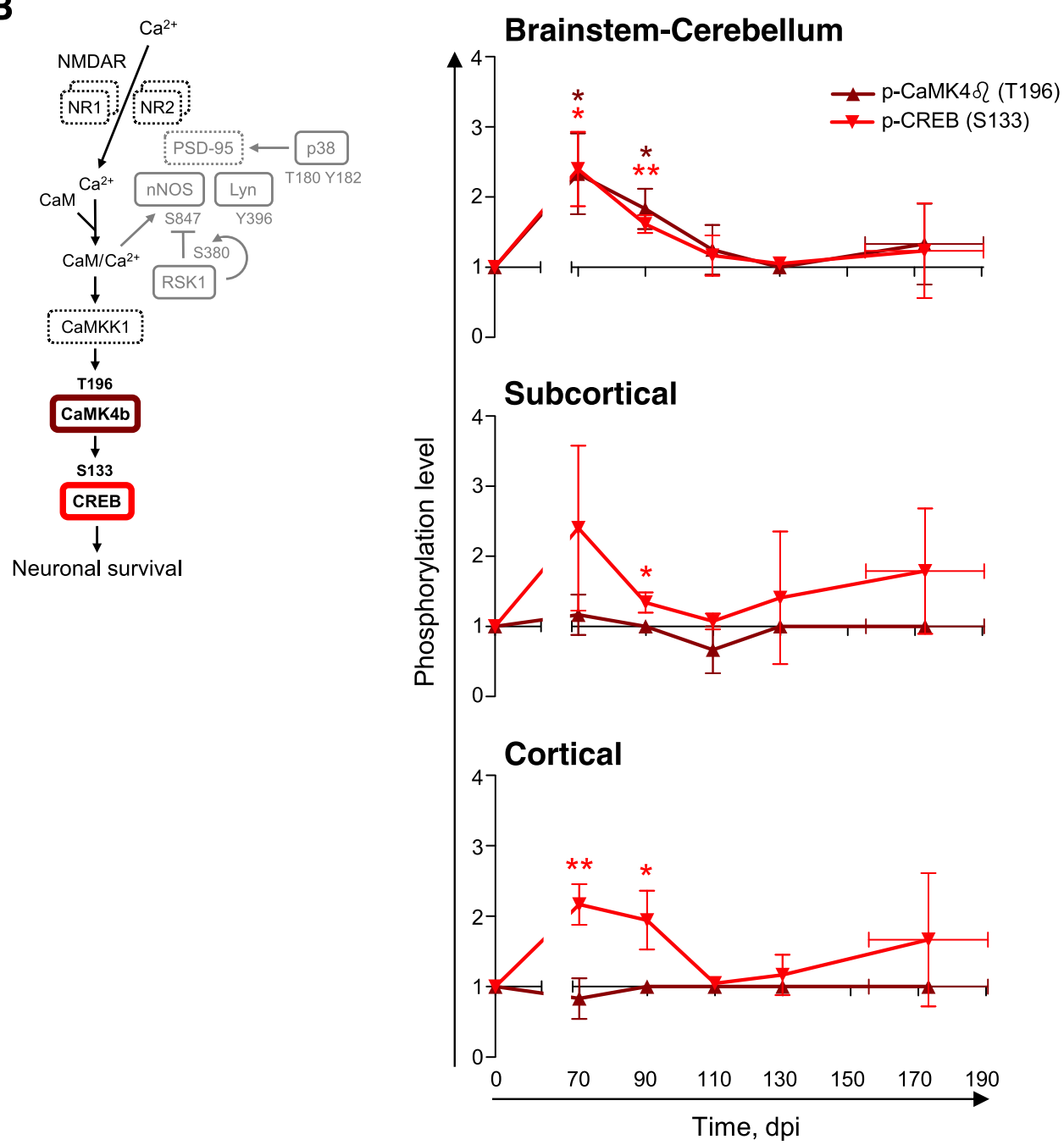

Figure 6 (See legend on next page.) 
(See figure on previous page.)

Figure 6 Activation of CaMK4 $\beta / C R E B$ signaling in scrapie-infected mice early in disease. Targeted tertiary analyses of the NMDAR-regulated CaMK4 $\beta$ signaling pathway in brainstem-cerebellum, subcortical and cortical regions of scrapie-infected mice at 70, 90, 110, $130 \mathrm{dpi}$ or at terminal stage of disease (TER; 155-190 dpi). (A) Levels of phosphorylated p38 (T180/Y182), Lyn (Y396), RSK1 (S380), nNOS (S847), CaMK4ß (T196), and CREB (S133) in the brainstem-cerebellums of each of the three scrapie-infected mice at each time, normalized to those in the mock-infected mice, shown by color bars. The proteins in dashed lines were not analyzed. (B) Levels of phosphorylated CaMK4 $\beta$ (T196) and CREB (S133) in all macrodissected regions, normalized to those in the mock-infected mice, shown as time series. Mean \pm SD; $n=3$ (Mean \pm range for CaMK4 $\beta$ (T196) at $90 \mathrm{dpi}$ [subcortical region] and $110 \mathrm{dpi}$ [brainstem-cerebellum], and CREB (S133) at $130 \mathrm{dpi}$ [brainstem-cerebellum]; $n=2)$. Error bars on the $x$-axes, range in time of onset of terminal disease. The differences in phosphorylation levels in scrapie- versus mock-infected mice were analyzed by two-tailed paired ratio $t$-test. ${ }^{*} P<0.05 ;{ }^{* *} P<0.01$.

death. Later (at $110 \mathrm{dpi}$ ), the neuroprotective CaMK4 $\beta$ / CREB signaling was lost and MST1 signaling was activated. Activation of MST1 signaling was associated with lower levels of full length MST1 and FOXO3. The decrease in full length MST1 was two-fold greater than the increase in the cleaved form (detected in the same blots with the same antibody). Cleaved MST1 may be less stable than full length MST, or full length MST1 may be processed by caspase-dependent and independent pathways.

The opposing changes in expression and activation state suggest an attempt to prevent the neuronal death that would result from activated MST1 signaling. The levels of upstream kinases DLK, MKK7, and JNK2 were also lower in scrapie-infected mice at $130 \mathrm{dpi}$, albeit only in the brainstem-cerebellum (Figure 7). The cerebellum (in the brainstem-cerebellum) may contain $\sim 50 \%$ of all neurons in an adult mouse brain [109] and loses the most neurons in RML-infected mice, as indicated by nuclear DNA fragmentation [96]. The changes in the total levels of proteins involved in the MST1 signaling pathway in each brain region may reflect the differences in the number of affected neurons in each brain region.

The different numbers of affected neurons in each region may also be reflected in the higher levels of total and phosphorylated CaMK $4 \beta$ in the brainstem-cerebellum than in the subcortical or cortical regions. Regardless of absolute numbers, higher levels of total and phosphorylated CREB were expressed in all brain regions. Although CaMK4 (P-T196) could also be responsible for CREB (P-S133) phosphorylation, there were no differences in the levels of activated CaMK4 (P-T196) in scrapie- versus mockinfected mice (data not shown). CREB is also phosphorylated on S133 by other protein kinases, including RSK, cAMP-dependent protein kinase (PKA), and mitogenactivated protein kinase-activated protein kinase 2 (MAPKAPK2) (for a review, see [110]). There was no correlation between the levels of active RSK1 (P-S380) and phosphorylated CREB (P-S133). We did not evaluate other protein kinases upstream of CREB because they were not identified in the primary screening. However, CREB may well be activated independently of CaMK4 $\beta$ in the cortical region or subcortical region of scrapie-infected mice.

The data presented cannot discriminate whether the observed changes in signaling pathways are a cause or a consequence of the pathology. Neither can discriminate whether they result from a loss of $\operatorname{PrP}^{\mathrm{C}}$ function, a gain of $\operatorname{PrP}^{\text {res }}$ function, or an altered signaling function resulting from the progressive $\mathrm{PrP}^{\mathrm{C}}$ misfolding into $\mathrm{PrP}^{\text {res }}$. Moreover, the dysregulation could have been directly triggered by $\operatorname{PrP}^{\text {res }}$ or $\operatorname{PrP}^{\mathrm{C}}$ acting on the neurons, or mediated by the glial alterations that occur during disease progression. The data presented does not resolve either whether the observed signaling changes are specific for prion diseases, or common to other neurodegenerative diseases. Future work will have to address these possibilities.

\section{Conclusion}

We used a kinomics approach to identify two dysregulated signaling pathways, involved in neuronal survival/ death, in scrapie-infected mice. Their dysregulation at different times during disease is temporally consistent with the neuronal loss during prion disease. Our findings identified novel signaling involved in prion-mediated neuronal death in vivo and identify potential targets for intervention. It is possible to test now the roles of these signaling pathways in prion disease, as well-characterized inhibitors of several of these proteins are available.

\section{Materials and methods}

\section{Ethics statement}

All of the procedures involving live animals were approved by the Canadian Science Centre for Human and Animal Health - Animal Care Committee (CSCHAH-ACC) or the University of British Columbia Animal Care Committee according to the guidelines set by the Canadian Council on Animal Care. The approval identifications for this study were animal use document (AUD)\#H-08-009 and AUD\#H-11-020.

\section{Animals and sample collection}

CD1 mice (Charles River Laboratories) between 4-6 weeks of age were infected intraperitoneally with the Rocky Mountain Laboratory (RML) mouse-adapted strain of scrapie. The inoculums consisted of $200 \mu \mathrm{l}$ of $1 \%$ brain homogenate in PBS from either clinically ill or normal control mice. Animals were sacrificed at 70, 90, 110, 130 days post infection (dpi) and terminal disease (155190 dpi). Clinical signs depicting terminal disease 
A

\section{Brainstem-Cerebellum}

\begin{tabular}{|c|c|c|c|c|}
\hline $70 \mathrm{dpi}$ & $90 \mathrm{dpi}$ & $110 \mathrm{dpi}$ & $130 \mathrm{dpi}$ & Termina \\
\hline DLK & DLK & DLK & & DLK \\
\hline$\downarrow$ & $\downarrow$ & $\downarrow$ & $\downarrow$ & $\downarrow$ \\
\hline MKKT & MKK & MKK7 & MKK & MKK \\
\hline$\downarrow$ & $\frac{1}{11}$ & $\frac{1}{1}$ & $\downarrow$ & $\downarrow$ \\
\hline$\frac{1}{d N h}$ & $\frac{1}{4 N n}$ & $\frac{e^{2} \sin 2}{\downarrow}$ & $\downarrow$ & $\underset{\downarrow}{\sinh 2}$ \\
\hline MST1 & MST1 & MST1 & & MST1 \\
\hline$\downarrow$ & $\frac{1}{1 \text { Fox }}$ & $\frac{1}{1 \text { FoxO3 }}$ & $\downarrow$ & $\frac{\downarrow}{\text { Fox03 }}$ \\
\hline
\end{tabular}

\section{Expression Level}

$\geq 1.51$

$1.31-1.50$

$1.11-1.30$

$0.91-1.10$

$0.71-0.90$

$0.51-0.70$

$0.01-0.50$

Not measurable

B

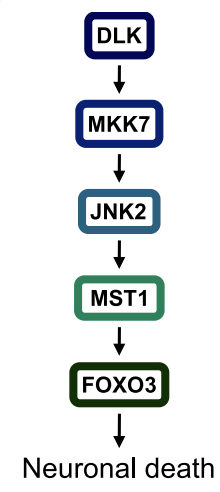

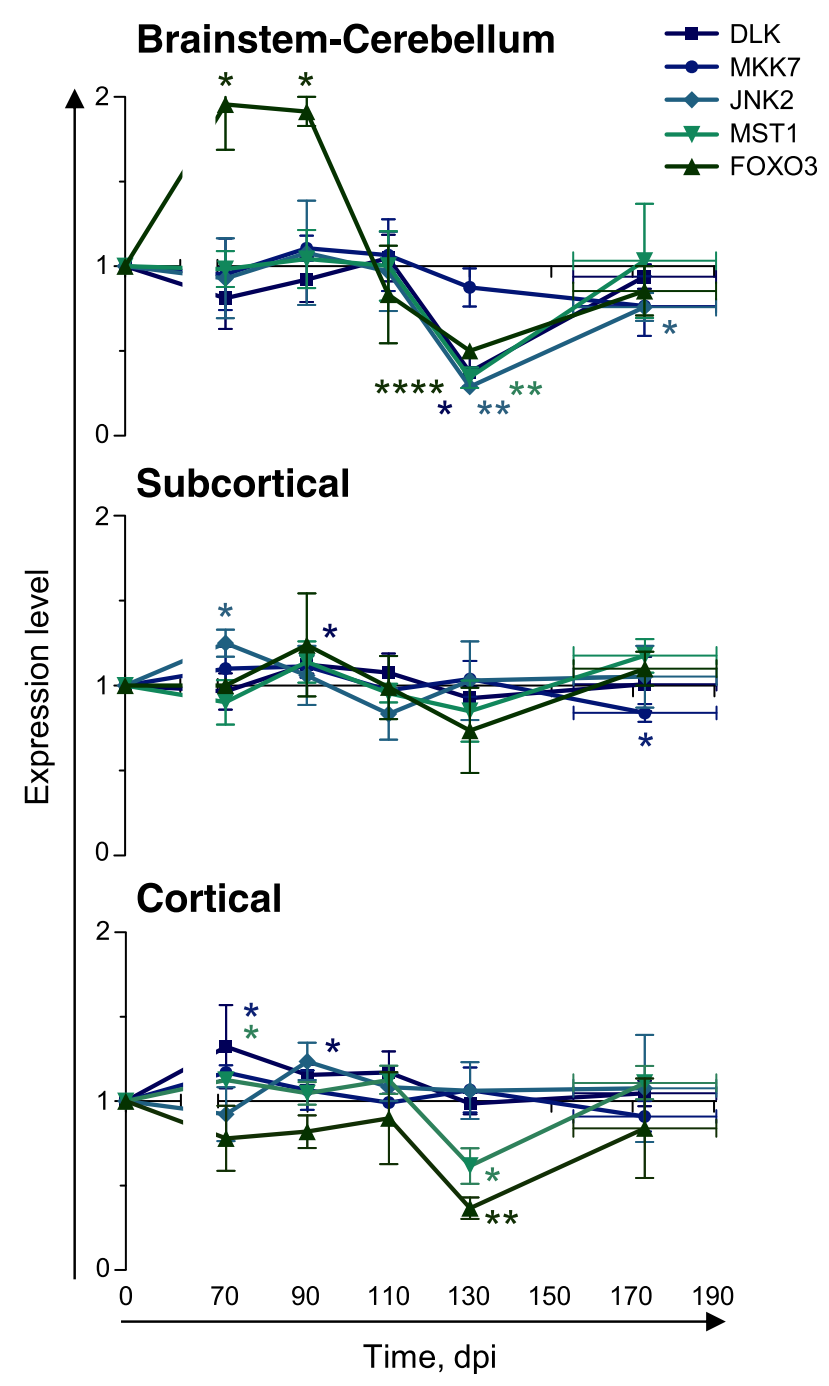

Figure $\mathbf{7}$ (See legend on next page.) 
(See figure on previous page.)

Figure 7 MST1 and FOXO3 are expressed to lower levels in scrapie-infected mice at $\mathbf{1 3 0} \mathbf{d p i}$. Targeted secondary analyses of the MST1 signaling pathway in brainstem-cerebellum, subcortical and cortical regions of scrapie-infected mice at 70, 90, 110, 130 dpi or at terminal stage of disease (TER; 155-190 dpi). (A) Levels of DLK, MKK7, JNK2, MST1, and FOXO3 in the brainstem-cerebellums of three scrapie-infected mice at each time point, normalized to those in the mock-infected mice, shown by color bars. (B) Protein levels in all macrodissected regions, normalized to those in mock-infected mice, shown as time series. Mean $\pm \mathrm{SD} ; n=3$ (Mean \pm range for FOXO3 at 90 dpi [brainstem-cerebellum] and TER [brainstem-cerebellum, subcortical region]; $n=2$ ). Error bars on the $x$-axes, range in time of onset of terminal disease. The differences in expression levels in scrapie- versus mock-infected mice were analyzed by two-tailed paired ratio $t$-test. ${ }^{*} P<0.05 ;{ }^{* *} P<0.01$; ${ }^{* * * *} P<0.0001$.

consisted of kyphosis, dull ruffled coat, weight loss of $20 \%$ or more and ataxia. Brain samples were collected and macrodissected into three sections, (i) cortical, (ii) subcortical (including thalamus, hypothalamus and hippocampus) and (iii) brainstem-cerebellum. Each section was flash frozen using a dry ice/methanol mixture and stored at $-80^{\circ} \mathrm{C}$ until processing. A total of 3 scrapie- and 3 mock-infected samples were collected per time point.

\section{Brain homogenization}

All procedures were performed at $4^{\circ} \mathrm{C}$ or on ice. Weighed frozen brainstem-cerebellum, subcortical, and cortical regions from mock- or scrapie-infected mice were homogenized in $3 \mathrm{~mL}$ of freshly prepared lysis buffer (20 mM MOPS [pH 7.0], 2 mM EGTA, $5 \mathrm{mM}$ EDTA, 1\% Nonidet P-40, 0.01\% phosphatase inhibitor cocktail [Pierce, Rockford, Illinois, USA], 0.02\% protease inhibitor cocktail [Sigma-Aldrich, St. Louis, Missouri, USA], $10 \mathrm{mM}$ DTT, pH 7.2) [111] per $250 \mathrm{mg}$ of brain, using a tissue homogenizer with disposable tips ( $\mathrm{TH}$ and hard tissue OMNI tip, respectively; OMNI International, Kennesaw, Georgia, USA). Brain homogenates were passed twice through a 21 gauge needle, sonicated five times for $20 \mathrm{~s}$ intervals at $88 \mathrm{~W}$ output (431C1 cup horn probe, S4000 sonicator; Qsonica, Newtown, Connecticut, USA), and pre-cleared by centrifugation for $30 \mathrm{~min}$ at $14,000 \times g$ (JLA 16.250 BC rotor, Avanti J-E centrifuge; Beckman/ Coulter, Brea, California, USA). Approximately $200 \mu \mathrm{L}$ aliquots of supernatant were aliquoted into $1.5 \mathrm{~mL}$ tubes, snap frozen in liquid nitrogen and stored at $-80^{\circ} \mathrm{C}$.

\section{Protein quantitation}

Protein concentration was determined by Bradford's assay (Bio-Rad Laboratories, Hercules, California, USA). Protein concentration and equal sample loading was re-tested in preliminary sodium dodecyl sulfate polyacrylamide gel electrophoresis (SDS-PAGE). Brain homogenates were mixed with an equal volume of $2 \mathrm{X}$ SDS loading buffer (125 mM Tris-Cl [pH 6.8], 20\% glycerol, 4\% SDS, 0.005\% bromophenol blue, $260 \mathrm{mM}$ DTT) and denatured by incubation at $100^{\circ} \mathrm{C}$ for $10 \mathrm{~min}$. Afterward, 15-well 8\% SDSPAGE gels (Mini-PROTEAN; Bio-Rad Laboratories) were loaded with $40 \mu \mathrm{g}$ of denatured protein per linear $\mathrm{cm}$ of well (running buffer; $190 \mathrm{mM}$ glycine, $24.8 \mathrm{mM}$ Tris, 0.1\% SDS, $\mathrm{pH}$ 8.3). Proteins were run through the stacking gel at $50 \mathrm{~V}$, and then resolved for $90 \mathrm{~min}$ at $100 \mathrm{~V}$, always at room temperature. Proteins were stained with Coomassie blue G-250 (Bio-Safe Coomassie; Bio-Rad Laboratories) according to the manufacturer's instructions. Signal from Coomassie-stained protein was detected using an Odyssey infrared imaging system (LI-COR Biosciences, Lincoln, Nebraska, USA) in the $700 \mathrm{~nm}$ channel and quantitated using Odyssey 3.0 software (LI-COR Biosciences). Protein amounts were calculated relative to a pre-quantitated standard brain homogenate.

\section{Sodium phosphotungstic acid precipitation}

Sodium phosphotungstic acid (NaPTA) precipitation was adapted from $[112,113]$. One milligram of mouse brain homogenate was mixed with an equal volume of $4 \%$ sodium lauroylsarcosine (sarkosyl) in PBS. Samples were incubated for $10 \mathrm{~min}$ at $37^{\circ} \mathrm{C}$ with constant agitation (1000 rpm, Thermomixer; Eppendorf, Hamburg, Germany). A $37^{\circ} \mathrm{C} \mathrm{NaPTA}$ solution (PBS, $4 \% \mathrm{NaPTA}, 170 \mathrm{mM} \mathrm{MgCl}$, $\mathrm{pH}$ 7.4) was then added to a final concentration of $0.3 \%$ NaPTA. Samples were incubated for $60 \mathrm{~min}$ at $37^{\circ} \mathrm{C}$ with constant agitation (1000 rpm, Thermomixer; Eppendorf), then centrifuged at $37^{\circ} \mathrm{C}$ for $30 \mathrm{~min}$ at $16,000 \times g(\mathrm{FA}-45$ 18-11 rotor, 5418 microfuge; Eppendorf). Pellets were resuspended in $5 \mu \mathrm{L}$ of $0.1 \%$ sarkosyl in PBS and digested with $20 \mu \mathrm{g}$ of proteinase $\mathrm{K}$ (PK; in $0.01 \mathrm{M} \mathrm{CaCl}_{2}$ ) (Roche, Indianapolis, Indiana, USA) for $30 \mathrm{~min}$ at $37^{\circ} \mathrm{C}$ with a brief vortex after $15 \mathrm{~min}$ [114]. Digestion was stopped and PKresistant protein was denatured by quickly adding an approximately equal volume 5X SDS loading buffer $(300 \mathrm{mM}$ Tris-Cl [pH 6.8], 50\% glycerol, 25\% $\beta$-mercaptoethanol, $10 \%$ SDS, $1 \%$ bromophenol blue), and immediately incubating at $100^{\circ} \mathrm{C}$ for $10 \mathrm{~min}$. Samples were resolved by SDSPAGE and analyzed by Western blot.

\section{Western blot}

All procedures were performed at room temperature and all washes were performed using gentle rocking, unless otherwise indicated.

$\operatorname{PrP}^{\text {res }}$ was analyzed in $1.0 \mathrm{mg}$ of NaPTA-enriched, PKtreated mouse brain homogenate using 15-well 12\% SDSPAGE gels (NuPAGE Novex Bis-Tris; Life Technologies Inc., Carlsbad, California, USA). The running buffer (50 mM MOPS, $50 \mathrm{mM}$ Tris, $1 \mathrm{mM}$ EDTA, 0.1\% SDS, $\mathrm{pH}$ 7.7) within the upper (cathode) chamber contained 


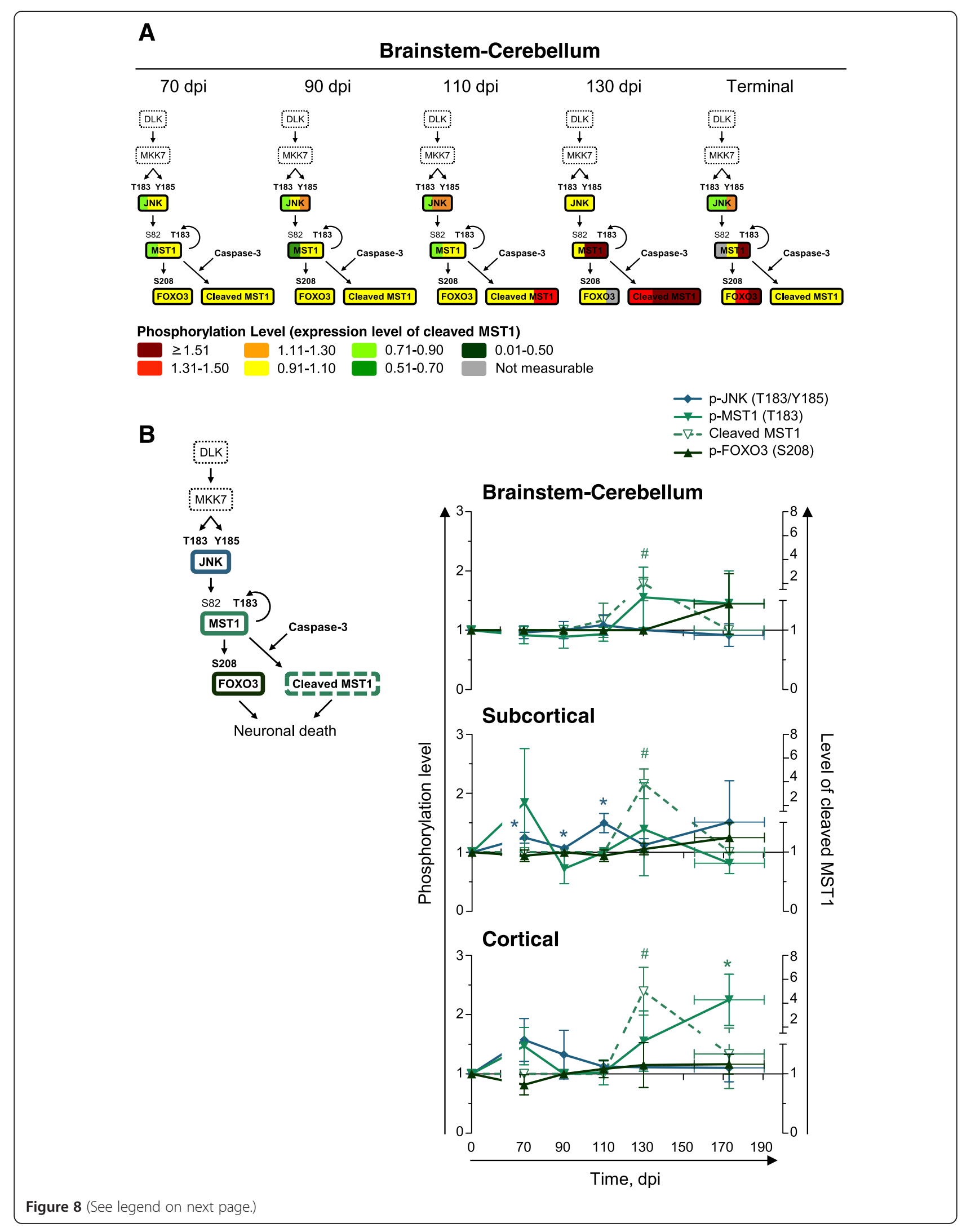


(See figure on previous page.)

Figure 8 Activation of MST1 in scrapie-infected mice at late stages of disease. Targeted tertiary analyses of MST1 signaling in brainstemcerebellum, subcortical region, and cortical region of scrapie-infected mice at 70, 90, 110, $130 \mathrm{dpi}$ or at terminal stage of disease (TER; 155-190 dpi). (A) Levels of phosphorylated JNK (T183/Y185), MST1 (T183), FOXO3 (S208), and cleaved MST1, in the brainstem-cerebellums of each of the three scrapie-infected mice at each time point, normalized to those in the mock-infected mice, shown by color bars. The proteins in dashed lines were not analyzed. (B) Phosphorylation levels in all brains regions, normalized to those in the mock-infected mice, shown as time series. Mean \pm SD; $n=3$ (Mean \pm range for MST1 (T183) at $110 \mathrm{dpi}$ [subcortical region] and TER [brainstem-cerebellum], and FOXO3 (S208) at $130 \mathrm{dpi}$ [brainstem-cerebellum] and TER [cortical region]; $n=2$ ). Error bars on the $x$-axes, range in time of onset of terminal disease. The differences in the phosphorylation levels, or levels of cleaved MST1, in scrapie- versus mock-infected mice were analyzed by two-tailed paired ratio $t$-test. * (\#, cleaved MST1), $P<0.05$.

$5 \mathrm{mM}$ sodium bisulfite. Proteins were run through the stacking gel at $60 \mathrm{~V}$, and then resolved for $2.5 \mathrm{~h}$ at $120 \mathrm{~V}$. Afterward, polyvinylidene fluoride (PVDF) membranes (Immuno-Blot, $0.2 \mu \mathrm{m}$; Bio-Rad Laboratories) were soaked in methanol for $2 \mathrm{~min}$, then equilibrated in transfer buffer (190 mM glycine, $24.5 \mathrm{mM}$ Tris, 10\% methanol) for $20 \mathrm{~min}$. Filter paper (2 sheets/membrane) were equilibrated in transfer buffer for $5 \mathrm{~min}$. Proteins were transferred at $4^{\circ} \mathrm{C}$ for $2 \mathrm{~h}$ at $30 \mathrm{~V}$. After transfer, membranes were dried, soaked in methanol for $2 \mathrm{~min}$ and washed twice for $10 \mathrm{~min}$ each in Tris-buffered saline (TBS; $140 \mathrm{mM} \mathrm{NaCl}, 3 \mathrm{mM} \mathrm{KCl}, 25 \mathrm{mM}$ Tris, $\mathrm{pH}$ 7.6). Membranes were blocked for $1 \mathrm{~h}$ in TBST (TBS/0.1\% Tween20) with $5 \%$ milk, then probed with PrP primary antibody (clone SAF83; a kind gift from Dr. Deborah McKenzie, University of Alberta) diluted to 1:10,000 in TBST with $5 \%$ milk for $18 \mathrm{~h}$ at $4^{\circ} \mathrm{C}$. Afterward, membranes were washed with TBST once for $5 \mathrm{~min}$ and thrice for $10 \mathrm{~min}$ each. Membranes were incubated with goat anti-mouse horseradish peroxidase (HRP)-labeled secondary antibody (Bio-Rad Laboratories) diluted to 1:40,000 in TBST with $5 \%$ milk for $1 \mathrm{~h}$. Membranes were washed in TBST once for $5 \mathrm{~min}$ and thrice for $15 \mathrm{~min}$ each, incubated for $5 \mathrm{~min}$ with enhanced chemiluminescent substrate (SuperSignal West Femto; Pierce) and then exposed to film (Super RX; Fujifilm, Tokyo, Japan). Exposed film was developed and scanned (CanoScan LiDE 200; Canon, Tokyo, Japan). Signal was quantitated using ImageJ (Version $1.47 \mathrm{c}$; National Institutes of Health, Bethesda, Maryland, USA).

To analyze GFAP and total PrP, brain homogenates were mixed with a one-fourth volume of 5X SDS loading buffer. Then, $100 \mu \mathrm{g}$ of denatured protein was loaded per linear cm onto 15-well 12\% SDS-PAGE gels (Mini-PROTEAN; Bio-Rad Laboratories). Proteins were run through the stacking gel at $50 \mathrm{~V}$, and then resolved for $100 \mathrm{~min}$ at $100 \mathrm{~V}$. Afterward, gels were equilibrated in transfer buffer (384 mM glycine, $49.6 \mathrm{mM}$ Tris, 20\% methanol, $0.01 \%$ SDS) [115] for $30 \mathrm{~min}$. PVDF membranes and filter paper (2 sheets/membrane) were also equilibrated in transfer buffer for 20 and $5 \mathrm{~min}$, respectively. Proteins were transferred for $23 \mathrm{~h}$ at $4^{\circ} \mathrm{C} ; 1 \mathrm{~h}$ at $54 \mathrm{~mA}, 4 \mathrm{~h}$ at $189 \mathrm{~mA}, 8 \mathrm{~h}$ at $270 \mathrm{~mA}$ and $10 \mathrm{~h}$ at $378 \mathrm{~mA}$. Membranes were blocked with 10\% blocking buffer (Sigma-Aldrich) for $1 \mathrm{~h}$ and probed simultaneously with primary antibodies specific for PrP (clone SAF83) and GFAP (Abcam Inc., Cambridge, Massachusetts, USA) diluted to $1: 10,000$ and 1:20,000 in $10 \%$ blocking buffer with $0.1 \%$ Tween-20, respectively, for $18 \mathrm{~h}$ at $4^{\circ} \mathrm{C}$. Afterward, membranes were washed with TBST once for $5 \mathrm{~min}$ and thrice for $10 \mathrm{~min}$ each. Membranes were then incubated for $1 \mathrm{~h}$ with donkey antimouse IRDye 680- (LI-COR Biosciences) and donkey antirabbit IRDye 800- (LI-COR Biosciences) labeled secondary

$$
\begin{aligned}
& \text { - CaMK4 } \beta / \mathrm{CREB} \\
& \text { - MST1 }
\end{aligned}
$$

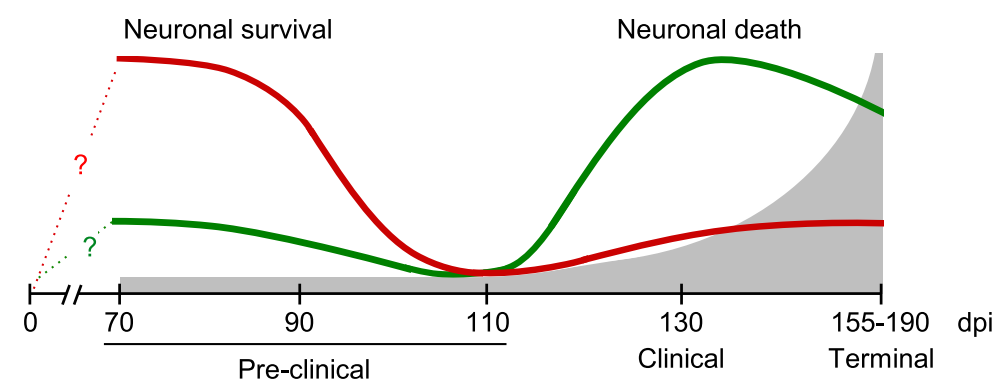

Figure $9 \mathrm{~A}$ model for the activation of signaling pathways involved in neuronal survival and death during scrapie pathogenesis. Relative activation states of CaMK4ß/CREB (red line) and MST1 (green line) signaling in scrapie-infected mice during disease progression, indicated in grey. Between 90 and $130 \mathrm{dpi}$, there is a switch from signaling involved in neuronal survival (activated CaMK4ß/CREB) to that involved in neuronal death (activated MST1). Adapted from [72] (Figure 7). 
antibodies diluted to 1:20,000 in 10\% blocking buffer with $0.1 \%$ Tween-20 and $0.01 \%$ SDS. Afterward, membranes were washed in TBST thrice for $10 \mathrm{~min}$ each, and once with TBS for $5 \mathrm{~min}$. Signal from pre-stained protein standards and IRDye 680-labeled secondary antibody was detected at $700 \mathrm{~nm}$ using an Odyssey infrared imaging system (LI-COR Biosciences). Signal from IRDye 800labeled secondary antibody was detected at $800 \mathrm{~nm}$. Signal was quantitated using Odyssey 3.0 software (LI-COR Biosciences). Membranes were then stained with Coomassie blue R-250 (Bio-Rad Laboratories) for $10 \mathrm{~min}$ before destaining with $40 \%$ methanol in $10 \%$ glacial acetic acid thrice for $10 \mathrm{~min}$ each, or until excess stain was removed. Signal from Coomassie-stained protein was detected at $700 \mathrm{~nm}$ using the Odyssey and quantitated using Odyssey 3.0 software.

For multiplex Western blots, brain homogenates were mixed with an equal volume of $2 \mathrm{X}$, or one-fifth volume of $6 \mathrm{X}$ (375 mM Tris-Cl [pH 6.8], 60\% glycerol, 12\% SDS, $0.015 \%$ bromophenol blue, $780 \mathrm{mM}$ DTT), SDS-PAGE loading buffer, and then $200 \mu \mathrm{g}$ of denatured protein was loaded per linear $\mathrm{cm}$ of single-well 8\% SDS-PAGE gels (Mini-PROTEAN; Bio-Rad Laboratories). Proteins were resolved as described for protein quantitation and transferred as described for Western blots of GFAP and total PrP. Dried membranes were probed immediately or stored at $-30^{\circ} \mathrm{C}$. All multiplex Western blots were performed in three sets, each composed of one membrane from a mock- and one from a scrapie-infected mouse euthanized at 70, 90,110, $130 \mathrm{dpi}$, or at terminal stage of disease. Membranes were blocked for $1 \mathrm{~h}$ with $10 \%$ blocking buffer (Sigma-Aldrich) for evaluation of total protein levels, or in 3\% BSA (Rockland, Gilbertsville, Pennsylvania, USA) for evaluation of phosphorylation levels. Membranes were rinsed briefly with TBS and positioned within a 24-lane multi-screen apparatus (MPX; LI-COR Biosciences). Combinations of primary antibodies were diluted in 10\% blocking buffer or 3\% BSA, as appropriate, with $0.1 \%$ Tween-20. One hundred sixty microliters of each antibody dilution was loaded in each lane of the multi-screen apparatus. After incubation for $18 \mathrm{~h}$ at $4^{\circ} \mathrm{C}$, membranes were briefly washed once with TBST within the multi-screen apparatus then removed from the apparatus and further washed in TBST, once for $5 \mathrm{~min}$ and four times for $15 \mathrm{~min}$ each. Membranes were incubated with secondary antibody diluted to $1: 20,000$ in $10 \%$ blocking buffer or $3 \%$ BSA, as appropriate, with $0.1 \%$ Tween-20 and $0.01 \%$ SDS for $1 \mathrm{~h}$. Mouse monoclonal primary antibodies were detected with donkey anti-mouse IRDye 680-labeled secondary antibody. Rabbit or goat primary polyclonal primary antibodies were detected with donkey anti-rabbit or donkey anti-goat IRDye 800-labeled secondary antibody (LI-COR Biosciences), respectively. Membranes were washed in TBST four times for $15 \mathrm{~min}$ each and once with TBS for $5 \mathrm{~min}$. Signal from IRDye 680- and IRDye 800-labeled secondary antibody was detected at 700 and $800 \mathrm{~nm}$, respectively, using the Odyssey system. Signal was quantitated using Odyssey 3.0 software.

Membranes from scrapie-infected mice were stripped (only once) together and in parallel with the membranes from the mock-infected mice from the same set, under conditions to minimize protein loss [116]. Membranes were stripped with mild stripping buffer $(25 \mathrm{mM}$ glycine, $1 \%$ SDS, $\mathrm{pH}$ 2.0) once for $5 \mathrm{~min}$ and four times for $15 \mathrm{~min}$ each, then with harsh stripping buffer $(50 \mathrm{mM}$ Tris-Cl [pH 7.0], 2\% SDS, $50 \mathrm{mM}$ DTT) [117] once for $15 \mathrm{~min}$ at $37^{\circ} \mathrm{C}$. Afterward, stripped membranes were washed with TBST once and TBS once for 5 min each, then blocked and reprobed with a second set of primary antibodies as described.

\section{Hierarchical cluster analysis}

For each set, the densitometric data from the primary multiplex Western blots of brainstem-cerebellum homogenates of scrapie-infected mice was normalized to that from the mock-infected mice. Relative protein kinase expression levels were then $\log _{2}$ transformed and analyzed with Gene Cluster 3.0 [118] using Euclidean distance and complete linkage. Java Treeview was used to present the clusters [119].

\section{Statistical analyses}

All data was analyzed using Prism (Version 5.0f; GraphPad Software Inc., La Jolla, California, USA). The targeted Western blots were performed in three experimental sets on different days. Each set encompassed one scrapie- and one mock-infected mouse from each time point. The ratios from each set were thus analyzed by paired $t$-test. The ratios were $\log$ transformed before analyses to transform the increased and decreased ratios (ratios greater or smaller than 1 , respectively) to proportional values. For nonlinear regression analyses, curves of the normalized total and phosphorylation protein levels in scrapie-infected mice were compared to no changes (a line with intercept $=1$, slope $=0$ ), representing the levels in mock-infected mice, using a replicates test for lack-of-fit.

\section{Additional files}

\footnotetext{
Additional file 1: Table S1. Accession numbers for the 130 protein kinases and 9 regulatory subunits analyzed in the primary multiplex Western blots. One hundred and twenty-four protein kinases or regulatory subunits included in our multiplex Western blots were detected in $200 \mu \mathrm{g}$ of mouse brain homogenate per linear well $\mathrm{cm}$. The other 15 (indicated by the asterisks) were detected in multiplex Western blots using an equivalent amount of lysate from cycling 3T3 mouse fibroblasts. The human accession number for each protein is indicated.

Additional file 2: Figure S1. CREB is expressed and phosphorylated to higher levels in the subcortical and cortical regions of scrapie- than
} 
mock-infected mice at 70 and $90 \mathrm{dpi}$. The normalized expression levels of p38y, Lyn, RSK1, CaMK4B, nNOS, CREB, and PSD-95 (A) or levels of phosphorylated p38 (T180/Y182), Lyn (Y396), RSK1 (S380), nNOS (S847), CaMK4 $\beta$ (T196), and CREB (S133) (B) in the subcortical and cortical regions of each of the three scrapie-infected mice each time point shown by color bars. The proteins in dashed lines were not analyzed.

Additional file 3: Figure S2. Lower levels of MST1 and FOXO3 are phosphorylated to higher levels in the subcortical and cortical regions of scrapie-infected mice at $130 \mathrm{dpi}$. The normalized expression levels of DLK, MKK7, JNK2, MST1 and FOXO3 (A) or levels of phosphorylated JNK (T183/Y185), MST1 (T183), FOXO3 (S208), and cleaved MST1 (B) in the subcortical and cortical regions of each of the three scrapie-infected mice at each time point shown by color bars. The proteins boxed in dashed lines were not analyzed.

\section{Competing interests}

The authors declare that they have no competing interests.

\section{Authors' contributions}

RHS prepared homogenates, performed the kinomic analyses and critically evaluated the results. KLF and AM performed the infections, collected and dissected the brains. LMS designed the study, critically evaluated the results, and co-wrote the manuscript with RHS. SAB and AM critically revised the manuscript. All authors have read and approved the final version of the manuscript.

\section{Acknowledgements}

This work was supported by PrioNet Canada and Alberta Prion Research Institute grants to LMS, a Burroughs Wellcome Fund Award to LMS. LMS is a Burroughs Wellcome Fund Investigator in the Pathogenesis of Infectious Disease. RHS was supported by NSERC, $75^{\text {th }}$ Anniversary Graduate Student Award (Faculty of Medicine and Dentistry, University of Alberta) and Queen Elizabeth II Doctoral Scholarship (Government of the Province of Alberta). We would like to thank Nicole Beausoleil and the staff at the NML animal house for the maintenance of mice used in this study.

\section{Author details}

'Department of Biochemistry and Centre for Prions and Protein Folding Diseases (CPPFD), University of Alberta, Edmonton, AB, Canada. ${ }^{2}$ Li Ka Shing Institute of Virology, University of Alberta, Edmonton, AB, Canada. ${ }^{3}$ Molecular PathoBiology, National Microbiology Laboratory, Public Health Agency of Canada, Winnipeg, MB, Canada. ${ }^{4}$ Department of Medical Microbiology and Infectious Diseases, University of Manitoba, Winnipeg, MB, Canada.

\section{Received: 5 June 2014 Accepted: 29 August 2014}

Published: 2 September 2014

\section{References}

1. Prusiner S: Prions. Proc Natl Acad Sci U S A 1998, 95:13363-13383.

2. Baeten L, Powers B, Jewell J, Spraker T, Miller M: A natural case of chronic wasting disease in a free-ranging moose (Alces alces shirasi). $J$ Wildl Dis 2007, 43:309-314.

3. Wadsworth J, Hill A, Beck J, Collinge J: Molecular and clinical classification of human prion disease. Br Med Bull 2003, 66:241-254

4. Paterson R, Torres-Chae C, Kuo A, Ando T, Nguyen E, Wong K, Dearmond S, Haman A, Garcia P, Johnson D, Miller B, Geschwind M: Differential diagnosis of jakob-creutzfeldt disease. Arch Neurol 2012, 69:1578-1582.

5. Mallucci G, Dickinson A, Linehan J, Klohn P, Brandner S, Collinge J: Depleting neuronal PrP in prion infection prevents disease and reverses spongiosis. Science 2003, 302:871-874.

6. Sakaguchi S: Systematic review of the therapeutics for prion diseases. Brain Nerve 2009, 61:929-938.

7. Sim V: Prion disease: chemotherapeutic strategies. Infect Disord Drug Targets 2012, 12:144-160

8. Wagner J, Ryazanov S, Leonov A, Levin J, Shi S, Schmidt F, Prix C, Pan-Montojo F, Bertsch U, Mitteregger-Kretzschmar G, Geissen M, Eiden M, Leidel F, Hirschberger T, Deeg A, Krauth J, Zinth W, Tavan P, Pilger J, Zweckstetter M, Frank T, Bahr M, Weishaupt J, Uhr M, Urlaub H, Teichmann U, Samwer M, Botzel K, Groschup M, Kretzschmar H, et al: Anle138b: a novel oligomer modulator for disease-modifying therapy of neurodegenerative diseases such as prion and Parkinson's disease. Acta Neuropathol 2013, 125:795-813.

9. Haik S, Marcon G, Mallet A, Tettamanti M, Welaratne A, Giaccone G, Azimi S, Pietrini V, Fabreguettes J, Imperiale D, Cesaro P, Buffa C, Aucan C, Lucca U, Peckeu L, Suardi S, Tranchant C, Zerr I, Houillier C, Redaelli V, Vespignani H, Campanella A, Sellal F, Krasnianski A, Seilhean D, Heinemann U, Sedel F, Canovi M, Gobbi M, Di Fede G, et al: Doxycycline in Creutzfeldt-Jakob disease: a phase 2, randomised, double-blind, placebo-controlled trial. Lancet Neurol 2014, 13:150-158.

10. Geschwind M, Kuo A, Wong K, Haman A, Devereux G, Raudabaugh B, Johnson D, Torres-Chae C, Finley R, Garcia P, Thai J, Cheng H, Neuhaus J, Forner S, Duncan J, Possin K, Dearmond S, Prusiner S, Miller B: Quinacrine treatment trial for sporadic Creutzfeldt-Jakob disease. Neurology 2013, 81:2015-2023.

11. Honda H, Sasaki K, Minaki H, Masui K, Suzuki S, Doh-Ura K, Iwaki T: Proteaseresistant PrP and PrP oligomers in the brain in human prion diseases after intraventricular pentosan polysulfate infusion. Neuropathology 2012, 32:124-132.

12. Terada T, Tsuboi Y, Obi T, Doh-ura K, Murayama S, Kitamoto T, Yamada T, Mizoguchi K: Less protease-resistant $\operatorname{PrP}$ in a patient with sporadic CJD treated with intraventricular pentosan polysulphate. Acta Neurol Scand 2010, 121:127-130.

13. Masullo $C$, Macchi $G, X i$ Y, Pocchiari M: Failure to ameliorate CreutzfeldtJakob disease with amphotericin B therapy. J Infect Dis 1992, 165:784-785.

14. Haik S, Brandel J, Salomon D, Sazdovitch V, Delasnerie-Laupretre N, Laplanche J, Faucheux B, Soubrie C, Boher E, Belorgey C, Hauw J, Alperovitch A: Compassionate use of quinacrine in Creutzfeldt-Jakob disease fails to show significant effects. Neurology 2004, 63:2413-2415.

15. Collinge J, Gorham M, Hudson F, Kennedy A, Keogh G, Pal S, Rossor M, Rudge P, Siddique D, Spyer M, Thomas D, Walker S, Webb T, Wroe S, Darbyshire J: Safety and efficacy of quinacrine in human prion disease (PRION-1 study): a patient-preference trial. Lancet Neurol 2009, 8:334-344.

16. Benito-Leon J: Combined quinacrine and chlorpromazine therapy in fatal familial insomnia. Clin Neuropharmacol 2004, 27:201-203.

17. Whittle I, Knight R, Will R: Unsuccessful intraventricular pentosan polysulphate treatment of variant Creutzfeldt-Jakob disease. Acta Neurochir (Wien) 2006, 148:677-679.

18. Tsuboi Y, Doh-Ura K, Yamada T: Continuous intraventricular infusion of pentosan polysulfate: clinical trial against prion diseases. Neuropathology 2009, 29:632-636.

19. Mukherjee A, Morales-Scheihing D, Gonzalez-Romero D, Green K, Taglialatela $G$, Soto C: Calcineurin inhibition at the clinical phase of prion disease reduces neurodegeneration, improves behavioral alterations and increases animal survival. PLOS Pathog 2010, 6:e1001138.

20. Johnson S, Hunter T: Kinomics: methods for deciphering the kinome. Nat Methods 2005, 2:17-25.

21. Kinase-Disease association. http://www.cellsignal.com/common/content/ content.jsp?id=science-tables-kinase-disease.

22. Martin L, Latypova X, Wilson C, Magnaudeix A, Perrin M, Yardin C, Terro F: Tau protein kinases: involvement in Alzheimer's disease. Ageing Res Rev 2013, 12:289-309.

23. Wood-Kaczmar A, Gandhi S, Wood N: Understanding the molecular causes of Parkinson's disease. Trends Mol Med 2006, 12:521-528.

24. Fabbro D, Cowan-Jacob S, Mobitz H, Martiny-Baron G: Targeting cancer with small-molecular-weight kinase inhibitors. Methods Mol Biol 2012, 795:1-34.

25. Bamborough P: System-based drug discovery within the human kinome. Expert Opin Drug Discov 2012, 7:1053-1070.

26. Knight Z, Lin H, Shokat K: Targeting the cancer kinome through polypharmacology. Nat Rev Cancer 2010, 10:130-137.

27. Cohen $P$, Alessi D: Kinase drug discovery-what's next in the field? ACS Chem Biol 2013, 8:96-104.

28. Clinical Trials of Protein Kinase Inhibitors. http://clinicaltrials.gov/ct2/ results?term=protein+kinase+inhibitor\&Search=Search.

29. Protein Kinase Inhibitors in Oncology Drug Pipeline Update 2014. http://www. researchandmarkets.com/reports/1196697/protein_kinase_inhibitors_ in_oncology_drug.

30. Arsenault R, Li Y, Potter A, Griebel P, Kusalik A, Napper S: Induction of ligand-specific PrP (C) signaling in human neuronal cells. Prion 2012 6:477-488.

31. Pan $B$, Yang LF, Wang J, Wang YS, Wang JH, Zhou XM, Yin XM, Zhang ZQ, Zhao DM: c-Abl Tyrosine Kinase Mediates Neurotoxic Prion Peptide- 
Induced Neuronal Apoptosis via Regulating Mitochondrial Homeostasis. Mol Neurobiol 2014, 49:1102-1116.

32. Perez M, Rojo Al, Wandosell F, Diaz-Nido J, Avila J: Prion peptide induces neuronal cell death through a pathway involving glycogen synthase kinase 3. Biochem J 2003, 372:129-136.

33. Moreno JA, Halliday M, Molloy C, Radford H, Verity N, Axten JM, Ortori CA Willis AE, Fischer PM, Barrett DA, Mallucci GR: Oral Treatment Targeting the Unfolded Protein Response Prevents Neurodegeneration and Clinical Disease in Prion-Infected Mice. Sci Transl Med 2013, 5(206):206ra138.

34. Pietri M, Dakowski C, Hannaoui S, Alleaume-Butaux A, Hernandez-Rapp J, Ragagnin A, Mouillet-Richard S, Haik S, Bailly Y, Peyrin J, Launay J, Kellermann O, Schneider B: PDK1 decreases TACE-mediated alpha-secretase activity and promotes disease progression in prion and Alzheimer's diseases. Nat Med 2013, 19:1124-1131.

35. Allen Brain Atlas. http://www.brain-map.org

36. Sakaguchi S, Katamine S, Shigematsu K, Nakatani A, Moriuchi R, Nishida N, Kurokawa K, Nakaoke R, Sato H, Jishage K: Accumulation of proteinase $\mathrm{K}$-resistant prion protein (PrP) is restricted by the expression level of normal PrP in mice inoculated with a mouse-adapted strain of the Creutzfeldt-Jakob disease agent. J Virol 1995, 69:7586-7592.

37. Lasmezas C, Deslys J, Demaimay R, Adjou K, Hauw J, Dormont D: Strain specific and common pathogenic events in murine models of scrapie and bovine spongiform encephalopathy. J Gen Virol 1996, 77:1601-1609.

38. Jendroska K, Heinzel F, Torchia M, Stowring L, Kretzschmar H, Kon A, Stern A, Prusiner S, DeArmond S: Proteinase-resistant prion protein accumulation in Syrian hamster brain correlates with regional pathology and scrapie infectivity. Neurology 1991, 41:1482-1490.

39. Jang B, Kim E, Choi J, Jin J, Kim J, Ishigami A, Maruyama N, Carp R, Kim Y, Choi E: Accumulation of citrullinated proteins by up-regulated peptidylarginine deiminase 2 in brains of scrapie-infected mice: a possible role in pathogenesis. Am J Pathol 2008, 173:1129-1142.

40. Baldauf $\mathrm{E}$, Beekes $\mathrm{M}$, Diringer $\mathrm{H}$ : Evidence for an alternative direct route of access for the scrapie agent to the brain bypassing the spinal cord. J Gen Virol 1997, 78:1187-1197.

41. Kimberlin R, Walker C: Pathogenesis of mouse scrapie: patterns of agent replication in different parts of the CNS following intraperitoneal infection. J R Soc Med 1982, 75:618-624.

42. Cole S, Kimberlin R: Pathogenesis of mouse scrapie: dynamics of vacuolation in brain and spinal cord after intraperitoneal infection. Neuropathol Appl Neurobiol 1985, 11:213-227.

43. Mabuchi T, Kitagawa K, Kuwabara K, Takasawa K, Ohtsuki T, Xia Z, Storm D, Yanagihara T, Hori M, Matsumoto M: Phosphorylation of cAMP response element-binding protein in hippocampal neurons as a protective response after exposure to glutamate in vitro and ischemia in vivo. J Neurosci 2001, 21:9204-9213.

44. Kalia L, Salter M: Interactions between Src family protein tyrosine kinases and PSD-95. Neuropharmacology 2003, 45:720-728.

45. Song T, Sugimoto K, Ihara H, Mizutani A, Hatano N, Kume K, Kambe T, Yamaguchi F, Tokuda M, Watanabe Y: p90 RSK-1 associates with and inhibits neuronal nitric oxide synthase. Biochem J 2007, 401:391-398.

46. Sabio G, Reuver S, Feijoo C, Hasegawa M, Thomas G, Centeno F, Kuhlendahl S, Leal-Ortiz S, Goedert M, Garner C, Cuenda A: Stress- and mitogen-induced phosphorylation of the synapse-associated protein SAP90/PSD-95 by activation of SAPK3/p38gamma and ERK1/ERK2. Biochem J 2004, 380:19-30.

47. Kmiecik T, Shalloway D: Activation and suppression of pp60c-src transforming ability by mutation of its primary sites of tyrosine phosphorylation. Cell 1987, 49:65-73.

48. Kmiecik T, Johnson P, Shalloway D: Regulation by the autophosphorylation site in overexpressed pp60c-src. Mol Cell Biol 1988, 8:4541-4546.

49. Vik T, Ryder J: Identification of serine 380 as the major site of autophosphorylation of Xenopus pp90rsk. Biochem Biophys Res Commun 1997, 235:398-402

50. Dalby K, Morrice N, Caudwell F, Avruch J, Cohen P: Identification of regulatory phosphorylation sites in mitogen-activated protein kinase (MAPK)-activated protein kinase-1a/p90rsk that are inducible by MAPK. J Biol Chem 1998, 273:1496-1505.

51. Matthews R, Guthrie C, Wailes L, Zhao X, Means A, McKnight G: Calcium/ calmodulin-dependent protein kinase types II and IV differentially regulate CREB-dependent gene expression. Mol Cell Biol 1994 14:6107-6116.
52. Ribar T, Rodriguiz R, Khiroug L, Wetsel W, Augustine G, Means A: Cerebellar defects in Ca2+/calmodulin kinase IV-deficient mice. J Neurosci 2000, 20:RC107.

53. Zhang S, Zou M, Lu L, Lau D, Ditzel D, Delucinge-Vivier C, Aso Y, Descombes $P$, Bading $\mathrm{H}$ : Nuclear calcium signaling controls expression of a large gene pool: identification of a gene program for acquired neuroprotection induced by synaptic activity. PLoS Genet 2009, 5:e1000604.

54. Tan Y, Zhang S, Hoffmann T, Bading H: Increasing levels of wild-type CREB up-regulates several activity-regulated inhibitor of death (AID) genes and promotes neuronal survival. BMC Neurosci 2012, 13:48.

55. Lehtinen M, Yuan Z, Boag P, Yang Y, Villen J, Becker E, DiBacco S, de la Iglesia N, Gygi S, Blackwell T, Bonni A: A conserved MST-FOXO signaling pathway mediates oxidative-stress responses and extends life span. Cell 2006, 125:987-1001.

56. Glantschnig H, Rodan G, Reszka A: Mapping of MST1 kinase sites of phosphorylation. Activation and autophosphorylation. J Biol Chem 2002, 277:42987-42996.

57. Kakeya H, Onose R, Osada H: Caspase-mediated activation of a 36-kDa myelin basic protein kinase during anticancer drug-induced apoptosis. Cancer Res 1998, 58:4888-4894.

58. Graves J, Gotoh Y, Draves K, Ambrose D, Han D, Wright M, Chernoff J, Clark E, Krebs E: Caspase-mediated activation and induction of apoptosis by the mammalian Ste20-like kinase Mst1. EMBO J 1998, 17:2224-2234.

59. Graves J, Draves K, Gotoh Y, Krebs E, Clark E: Both phosphorylation and caspase-mediated cleavage contribute to regulation of the Ste20-like protein kinase Mst1 during CD95/Fas-induced apoptosis. J Biol Chem 2001, 276:14909-14915.

60. Lee K, Ohyama T, Yajima N, Tsubuki S, Yonehara S: MST, a physiological caspase substrate, highly sensitizes apoptosis both upstream and downstream of caspase activation. J Biol Chem 2001, 276:19276-19285.

61. Bi W, Xiao L, Jia Y, Wu J, Xie Q, Ren J, Ji G, Yuan Z: c-Jun N-terminal kinase enhances MST1-mediated pro-apoptotic signaling through phosphorylation at serine 82. J Biol Chem 2010, 285:6259-6264.

62. Mantamadiotis T, Lemberger T, Bleckmann S, Kern H, Kretz O, Martin Villalba A, Tronche F, Kellendonk C, Gau D, Kapfhammer J, Otto C, Schmid W, Schutz G: Disruption of CREB function in brain leads to neurodegeneration. Nat Genet 2002, 31:47-54.

63. Jancic D, Lopez de Armentia M, Valor L, Olivares R, Barco A: Inhibition of cAMP response element-binding protein reduces neuronal excitability and plasticity, and triggers neurodegeneration. Cereb Cortex 2009, $19: 2535-2547$

64. Ao H, Ko S, Zhuo M: CREB activity maintains the survival of cingulate cortical pyramidal neurons in the adult mouse brain. Mol Pain 2006, 2:15

65. Vo N, Klein M, Varlamova O, Keller D, Yamamoto T, Goodman R, Impey S: A cAMP-response element binding protein-induced microRNA regulates neuronal morphogenesis. Proc Natl Acad Sci U S A 2005, 102:16426-16431.

66. Nudelman A, DiRocco D, Lambert T, Garelick M, Le J, Nathanson N, Storm D: Neuronal activity rapidly induces transcription of the CREB-regulated microRNA-132, in vivo. Hippocampus 2010, 20:492-498.

67. Magill S, Cambronne X, Luikart B, Lioy D, Leighton B, Westbrook G, Mandel $G$, Goodman R: microRNA-132 regulates dendritic growth and arborization of newborn neurons in the adult hippocampus. Proc Nat Acad Sci U S A 2010, 107:20382-20387.

68. Hwang D, Lee I, Yoo H, Gehlenborg N, Cho J, Petritis B, Baxter D, Pitstick R, Young R, Spicer D, Price N, Hohmann J, Dearmond S, Carlson G, Hood L: A systems approach to prion disease. Mol Syst Biol 2009, 5:252.

69. Booth S, Bowman C, Baumgartner R, Sorensen G, Robertson C, Coulthart M, Phillipson C, Somorjai R: Identification of central nervous system genes involved in the host response to the scrapie agent during preclinical and clinical infection. $J$ Gen Virol 2004, 85:3459-3471.

70. Moody L, Herbst A, Yoo H, Vanderloo J, Aiken J: Comparative prion disease gene expression profiling using the prion disease mimetic, cuprizone. Prion 2009, 3:99-109.

71. Brown A, Rebus S, McKimmie C, Robertson K, Williams A, Fazakerley J: Gene expression profiling of the preclinical scrapie-infected hippocampus. Biochem Biophys Res Commun 2005, 334:86-95.

72. Majer A, Medina S, Niu Y, Abrenica B, Manguiat K, Frost K, Philipson C, Sorensen D, Booth S: Early mechanisms of pathobiology are revealed by transcriptional temporal dynamics in hippocampal CA1 neurons of prion infected mice. PLoS Pathog 2012, 8:e1003002. 
73. Kim H, Snyder G, Blazey T, Race R, Chesebro B, Skinner P: Prion disease induced alterations in gene expression in spleen and brain prior to clinical symptoms. Adv Appl Bioinform Chem 2008, 1:29-50

74. Kasahara J, Fukunaga K, Miyamoto E: Differential effects of a calcineurin inhibitor on glutamate-induced phosphorylation of Ca2+/calmodulindependent protein kinases in cultured rat hippocampal neurons. J Biol Chem 1999, 274:9061-9067.

75. Bito $H$, Deisseroth $K$, Tsien R: CREB phosphorylation and dephosphorylation: a $\mathrm{Ca}(2+)$ - and stimulus duration-dependent switch for hippocampal gene expression. Cell 1996, 87:1203-1214.

76. Agostinho P, Oliveira C: Involvement of calcineurin in the neurotoxic effects induced by amyloid-beta and prion peptides. Eur J Neurosci 2003, 17:1189-1196.

77. Nakagaki T, Satoh K, Ishibashi D, Fuse T, Sano K, Kamatari Y, Kuwata K, Shigematsu K, Iwamaru Y, Takenouchi T, Kitani H, Nishida N, Atarashi R: FK506 reduces abnormal prion protein through the activation of autolysosomal degradation and prolongs survival in prion-infected mice. Autophagy 2013, 9(9):1386-1394.

78. McGinnis K, Whitton M, Gnegy M, Wang K: Calcium/calmodulin-dependent protein kinase IV is cleaved by caspase-3 and calpain in SH-SY5Y human neuroblastoma cells undergoing apoptosis. J Biol Chem 1998, 273:19993-20000.

79. Watt F, Molloy P: Specific cleavage of transcription factors by the thiol protease, m-calpain. Nucleic Acids Res 1993, 21:5092-5100.

80. See $V$, Loeffler J: Oxidative stress induces neuronal death by recruiting a protease and phosphatase-gated mechanism. J Biol Chem 2001, 276:35049-35059.

81. Guo Y, Gong H, Zhang J, Xie W, Tian C, Chen C, Shi Q, Wang S, Xu Y, Zhang $\mathrm{B}$, Dong X: Remarkable reduction of MAP2 in the brains of scrapieinfected rodents and human prion disease possibly correlated with the increase of calpain. PLoS One 2012, 7:e30163.

82. O'Donovan C, Tobin D, Cotter T: Prion protein fragment PrP-(106-126) induces apoptosis via mitochondrial disruption in human neuronal SH-SY5Y cells. J Biol Chem 2001, 276:43516-43523.

83. Falsig J, Sonati T, Herrmann U, Saban D, Li B, Arroyo K, Ballmer B, Liberski P, Aguzzi A: Prion pathogenesis is faithfully reproduced in cerebellar organotypic slice cultures. PLoS Pathog 2012, 8:e1002985.

84. Lopes J, Oliveira C, Agostinho P: Role of cyclin-dependent kinase 5 in the neurodegenerative process triggered by amyloid-Beta and prion peptides: implications for Alzheimer's disease and prion-related encephalopathies. Cell Mol Neurobiol 2007, 27:943-957.

85. Wadzinski B, Wheat W, Jaspers S, Peruski LJ, Lickteig R, Johnson G, Klemm D: Nuclear protein phosphatase $2 \mathrm{~A}$ dephosphorylates protein kinase A-phosphorylated CREB and regulates CREB transcriptional stimulation. Mol Cell Biol 1993, 13:2822-2834.

86. Park I, Soderling T: Activation of $\mathrm{Ca} 2+/$ calmodulin-dependent protein kinase (CaM-kinase) IV by CaM-kinase kinase in Jurkat T lymphocytes. J Biol Chem 1995, 270:30464-30469.

87. Westphal $R$, Anderson K, Means A, Wadzinski B: A signaling complex of $\mathrm{Ca} 2+-$ calmodulin-dependent protein kinase IV and protein phosphatase 2A. Science 1998, 280:1258-1261.

88. Lee J, Shin J, Hwang S, Gwag B, McKee A, Lee J, Kowall N, Ryu H, Lim D, Choi E: MST1 functions as a key modulator of neurodegeneration in a mouse model of ALS. Proc Natl Acad Sci U S A 2013, 110:12066-12071.

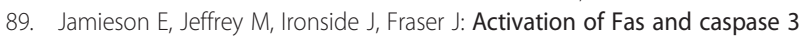
precedes PrP accumulation in 87 V scrapie. Neuroreport 2001, 12:3567-3572.

90. Hetz C, Russelakis-Carneiro M, Maundrell K, Castilla J, Soto C: Caspase-12 and endoplasmic reticulum stress mediate neurotoxicity of pathological prion protein. EMBO J 2003, 22:5435-5445.

91. Corsaro A, Thellung S, Villa V, Principe D, Paludi D, Arena S, Millo E, Schettini D, Damonte G, Aceto A, Schettini G, Florio T: Prion protein fragment 106-126 induces a p38 MAP kinase-dependent apoptosis in SH-SY5Y neuroblastoma cells independently from the amyloid fibril formation. Ann N Y Acad Sci 2003, 1010:610-622.

92. White A, Guirguis R, Brazier M, Jobling M, Hill A, Beyreuther K, Barrow C, Masters C, Collins S, Cappai R: Sublethal concentrations of prion peptide PrP106-126 or the amyloid beta peptide of Alzheimer's disease activates expression of proapoptotic markers in primary cortical neurons. Neurobiol Dis 2001, 8:299-316.

93. Praskova M, Khoklatchev A, Ortiz-Vega S, Avruch J: Regulation of the MST1 kinase by autophosphorylation, by the growth inhibitory proteins, RASSF1 and NORE1, and by Ras. Biochem J 2004, 381:453-462.
94. Cheung W, Ajiro K, Samejima K, Kloc M, Cheung P, Mizzen C, Beeser A, Etkin L, Chernoff J, Earnshaw W, Allis C: Apoptotic phosphorylation of histone $\mathrm{H} 2 \mathrm{~B}$ is mediated by mammalian sterile twenty kinase. Cell 2003 , 113:507-517.

95. Schatzl H, Laszlo L, Holtzman D, Tatzelt J, DeArmond S, Weiner R, Mobley W, Prusiner S: A hypothalamic neuronal cell line persistently infected with scrapie prions exhibits apoptosis. J Virol 1997, 71:8821-8831.

96. Siso S, Puig B, Varea R, Vidal E, Acin C, Prinz M, Montrasio F, Badiola J, Aguzzi A, Pumarola M, Ferrer I: Abnormal synaptic protein expression and cell death in murine scrapie. Acta Neuropathol 2002, 103:615-626.

97. Giese A, Groschup M, Hess B, Kretzschmar H: Neuronal cell death in scrapie-infected mice is due to apoptosis. Brain Pathol 1995, 5:213-221.

98. Williams A, Lucassen P, Ritchie D, Bruce M: PrP deposition, microglial activation, and neuronal apoptosis in murine scrapie. Exp Neurol 1997, 144:433-438.

99. Saez-Valero J, Angeretti N, Forloni G: Caspase-3 activation by beta-amyloid and prion protein peptides is independent from their neurotoxic effect. Neurosci Lett 2000, 293:207-210.

100. Engelstein R, Grigoriadis N, Greig N, Ovadia H, Gabizon R: Inhibition of P53-related apoptosis had no effect on $\operatorname{PrP}(\mathrm{Sc})$ accumulation and prion disease incubation time. Neurobiol Dis 2005, 18:282-285.

101. Brunet A, Bonni A, Zigmond M, Lin M, Juo P, Hu L, Anderson M, Arden K, Blenis J, Greenberg M: Akt promotes cell survival by phosphorylating and inhibiting a Forkhead transcription factor. Cell 1999, 96:857-868.

102. Ura S, Masuyama N, Graves J, Gotoh Y: Caspase cleavage of MST promotes nuclear translocation and chromatin condensation. Proc Natl Acad Sci U S A 2001, 98:10148-10153.

103. Anand R, Kim A, Brent M, Marmorstein R: Biochemical analysis of MST1 kinase: elucidation of a C-terminal regulatory region. Biochemistry 2008, 47:6719-6726.

104. You H, Pellegrini M, Tsuchihara K, Yamamoto K, Hacker G, Erlacher M, Villunger A, Mak T: FOXO3a-dependent regulation of Puma in response to cytokine/growth factor withdrawal. J Exp Med 2006, 203:1657-1663.

105. Czymai T, Viemann D, Sticht C, Molema G, Goebeler M, Schmidt M: FOXO3 modulates endothelial gene expression and function by classical and alternative mechanisms. J Biol Chem 2010, 285:10163-10178.

106. Obexer P, Geiger K, Ambros P, Meister B, Ausserlechner M: FKHRL1mediated expression of Noxa and Bim induces apoptosis via the mitochondria in neuroblastoma cells. Cell Death Differ 2007, 14:534-547.

107. Hetz C, Lee A, Gonzalez-Romero D, Thielen P, Castilla J, Soto C, Glimcher L: Unfolded protein response transcription factor XBP-1 does not influence prion replication or pathogenesis. Proc Natl Acad Sci U S A 2008, 105:757-762.

108. Steele A, King O, Jackson W, Hetz C, Borkowski A, Thielen P, Wollmann R, Lindquist S: Diminishing apoptosis by deletion of Bax or overexpression of $\mathrm{BCl}-2$ does not protect against infectious prion toxicity in vivo. J Neurosci 2007, 27:13022-13027.

109. Fu Y, Rusznak Z, Herculano-Houzel S, Watson C, Paxinos G: Cellular composition characterizing postnatal development and maturation of the mouse brain and spinal cord. Brain Struct Funct 2013, 218:1337-1354.

110. Johannessen M, Delghandi M, Moens U: What turns CREB on? Cell Signal 2004, 16:1211-1227.

111. Pelech S, Sutter C, Zhang H: Kinetworks protein kinase multiblot analysis. Methods Mol Biol 2003, 218:99-111.

112. Safar J, Wille H, Itri V, Groth D, Serban H, Torchia M, Cohen F, Prusiner S: Eight prion strains have $\operatorname{Pr} P(\mathrm{Sc})$ molecules with different conformations. Nat Med 1998, 4:1157-1165.

113. Wadsworth J, Joiner S, Hill A, Campbell T, Desbruslais M, Luthert $P$, Collinge J: Tissue distribution of protease resistant prion protein in variant Creutzfeldt-Jakob disease using a highly sensitive immunoblotting assay. Lancet 2001, 358:171-180.

114. Kumar R, McClain D, Young R, Carlson G: Cholesterol transporter ATP-binding cassette $A 1$ (ABCA1) is elevated in prion disease and affects PrPC and PrPSc concentrations in cultured cells. J Gen Virol 2008, 89:1525-1532

115. Otter T, King S, Witman G: A two-step procedure for efficient electrotransfer of both high-molecular-weight (greater than 400,000) and low-molecularweight (less than 20,000) proteins. Anal Biochem 1987, 162:370-377.

116. Yeung $Y$, Stanley $E$ : A solution for stripping antibodies from polyvinylidene fluoride immunoblots for multiple reprobing. Anal Biochem 2009, 389:89-91. 
117. Harlow E, Lane D: Using Antibodies: A Laboratory Manual. New York: Cold Spring Harbor Laboratory Press; 1999.

118. de Hoon M, Imoto S, Nolan J, Miyano S: Open source clustering software. Bioinformatics 2004, 20:1453-1454.

119. Saldanha A: Java Treeview-extensible visualization of microarray data. Bioinformatics 2004, 20:3246-3248.

doi:10.1186/1743-422X-11-160

Cite this article as: Shott et al:: Activation of Pro-survival CaMK4 $\beta / C R E B$ and Pro-death MST1 signaling at early and late times during a mouse model of prion disease. Virology Journal 2014 11:160.

\section{Submit your next manuscript to BioMed Central} and take full advantage of:

- Convenient online submission

- Thorough peer review

- No space constraints or color figure charges

- Immediate publication on acceptance

- Inclusion in PubMed, CAS, Scopus and Google Scholar

- Research which is freely available for redistribution 